\title{
12. NEOGENE RADIOLARIANS FROM THE EASTERN NORTH PACIFIC (OFF ALTA AND BAJA CALIFORNIA), DEEP SEA DRILLING PROJECT LEG 631
}

\author{
Reinhard Wolfart, Federal Institute of Geosciences and Natural Resources, Hannover, Federal Republic of Germany
}

\section{INTRODUCTION}

Leg 63 of the Deep Sea Drilling Project extended along the west coast of North America and northern Central America, northwest of Los Angeles to southwest of Mazatlan, Mexico. Holes were drilled at seven sites and Neogene cores recovered, exclusively (Sites 467-473). Sites 467 through 469 are situated within the California Continental Borderland, Sites 470 through 473 within the western continental margin of Baja California (Fig. 1). Leg 63 drilling was intended to study the Neogene paleooceanographical and climatological development of the northeastern Pacific and the evolution of planktonic communities.

\section{METHODS}

Light-microscope techniques were used to study the Neogene radiolarians of 429 samples. Radiolarian zonation of the samples, summarized in Fig. 2, follows mainly Hays (1970), Kling (1973), Riedel and Sanfilippo (1971, 1978), Moore (1971), Dinkelman (1973), and Foreman (1975).

The relative abundances of the various species were determined as follows. All individuals of each species were counted. After 15 individuals of one species were noted, the counting stopped, yielding the relative abundances for each species: A, abundant (more than 15 specimens on the counted part of a slide); C, common (10-14 specimens); F, few (5-9 specimens); R, rare ( $1-4$ specimens). B, barren (no recognizable specimens).

The taxonomy, which is alphabetically arranged, references only papers in which the species mentioned are fully described.

\section{SITE SUMMARIES}

\section{Site 467}

Site 467 is located within the San Miguel Gap (Table 1), about $230 \mathrm{~km}$ northwest of Los Angeles. Coring was intended to provide a Miocene through Quaternary reference section that would permit biostratigraphical correlations between the California Borderland and the California province (onshore). Neogene radiolarianbearing sediments were recovered from Cores 467-2 through 56 (Quaternary through uppermost Miocene); the radiolarian abundance is generally rare to few, the preservation poor to moderate. No datable radiolarians are known from Cores 22, 31, 37, 46, and 57 through 110. The radiolarian assemblages from Cores 2 through 56 are listed in Table 2. The biostratigraphical zonation used here follows Hays (1970) and Kling (1973) for the eastern North Pacific.

\footnotetext{
${ }^{1}$ Initial Reports of the Deep Sea Drilling Project, Volume 63.
}

In Section 2-1 through Section 8-4, radiolarians were deposited in the early late Pleistocene (Axoprunum angelinum Zone), indicated by the presence of Lamprocyrtis nigriniae and Lamprocyrtis neoheteroporos and the absence of Eucyrtidium matuyamai. Because of the presence of E. matuyamai and Lamprocyrtis heteroporos, Section 8-5 through Sample 10,CC must be placed-at least in the upper part-in the lower Pleistocene (E. matuyamai Zone).

Sections 11-1 through 25-8 are in the upper Pliocene $L$. heteroporos Zone, as indicated by the occurrence of a radiolarian assemblage with $L$. heteroporos and without E. matuyamai and Stichocorys peregrina. The first typical specimens of $S$. peregrina in Section 26-2 indicate deposition in the early Pliocene. They are associated with $L$. heteroporos and some nondiagnostic Neogene radiolarians. The lower Pliocene succession comprises Section 26-2 through Sample 45,CC. L. heteroporos does not occur below Sample 45,CC. This and the presence of $S$. peregrina suggest that Core 47 through Core 56, Section 2 were deposited in the late late Miocene (lower part of S. peregrina Zone). Rare specimens of various Cyrtocapsella species were found in Pliocene beds; they are reworked from older layers of the Miocene.

The hard rocks of Cores 57 through 110 contain very rare (e.g., Core 58) and poorly preserved radiolarians that cannot be dated. A significant feature of the Pleistocene-Pliocene radiolarian assemblages within the range of the California Current west-northwest of Los Angeles is the absence of the stratigraphically important species of equatorial regions (Amphirhopalum ypsilon, Anthocyrtidium angulare, Ommatartus tetrathalamus, Pterocanium praetextum, $P$. prismatium, Spongaster tetras, S. pentas, Theocorythium spp.). Kling (1973) points out this same feature for the region north of Los Angeles (off Cape Mendocino). The Pleistocene-Pliocene radiolarian assemblages at Site 467 resemble those of the subarctic North Pacific. Equatorial taxa ( $S$. peregrina, Cyrtocapsella) in upper Miocene sediments of Site 467, however, suggest an influence of equatorial waters at that time. These forms do not replace the normal California Current assemblage, but they appear in addition to it.

\section{Site $\mathbf{4 6 8}$}

Hole 468 was drilled on the Patton Escarpment to find clues to the late Cenozoic paleoceanographicpaleoclimatic history and the associated oscillations in the biogeographic patterns of planktonic communities. 


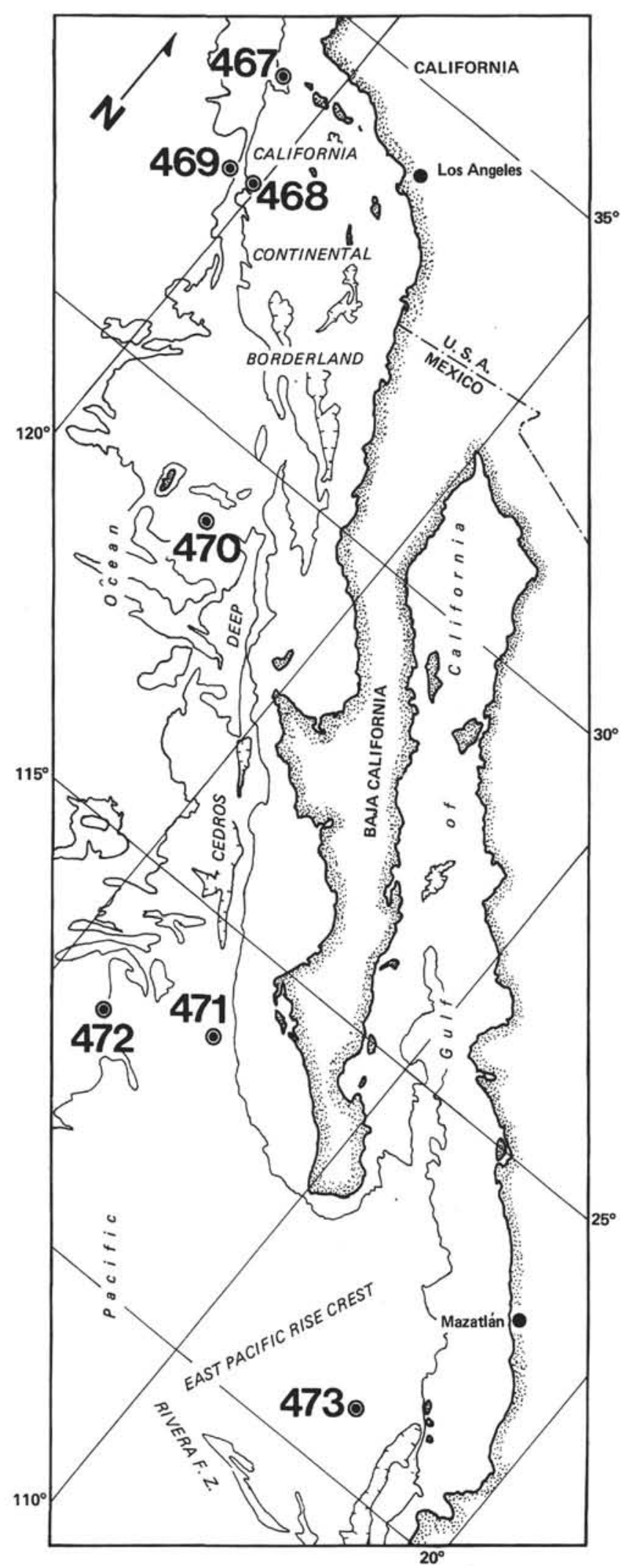

Figure 1. Locations of Leg 63 drilling sites.
Hole 468 was continuously cored to 241 meters, Hole $468 \mathrm{~A}$ to 35.5 meters, and Hole $468 \mathrm{~B}$ to 415.5 meters. A relatively thin cover $(3.5-40 \mathrm{~m})$ of upper Neogene sediment rich in calcareous microfossils and rather poor in siliceous microfossils overlies a thicker sequence of calcareous and siliceous middle Miocene sediment. This, in turn, overlies a barren sedimentary sequence that may represent either middle or lower Miocene.

The radiolarian abundance in Quaternary through middle Miocene sediments is mostly rare to few and the preservation poor to moderate. Only few cores contain common to abundant, well-preserved radiolariansSections 2-1 through 3-1 and Sections 4-5 through 5-1 (Hole 468), and Sections 3-2 through 9-2 (Hole 468B). Core 1 and Core 2, Section 1 (Hole 468A) contain a well-preserved, common Pleistocene radiolarian assemblage. Surface sediment in Hole 468A yields no datable radiolarians as well as Cores 14 through 16 of Hole 468 and Core 5 of Hole 468B. Below Section 468B-18-2, no remains of radiolarians occur (except in Sample 29,CC). Tables 3 and 4 list the radiolarian assemblages from the Neogene sediments of these holes.

The Quaternary sediments of Hole 468A yielded radiolarian assemblages described from the northeastern Pacific, and Kling's (1973) zonation is applicable. Sections 1 and 2 of Core 1 correlate with the upper Pleistocene Axoprunum angelinum Zone, as indicated by the presence of Lamprocyrtis nigriniae and the absence of E. matuyamai. The assemblages of Section 1-3 through Section 2-1, containing E. matuyamai and Lamprocyrtis heteroporos are-at least the upper part-assigned to the lower Pleistocene E. matuyamai Zone. Single specimens of Amphirhopalum ypsilon and Theocorythium vetulum, which are typical of equatorial regions, are included in the Quaternary assemblages. The upper Pliocene sediments of Hole 468A (Section 2-2 through Sample 2,CC) and Hole 468B (Sections 1-1 through 1-2) contain only nondiagnostic radiolarians besides Lamprocyrtis heteroporos and belong, therefore, to the $L$. heteroporos Zone. The upper boundary of the lower Pliocene/uppermost Miocene Stichocorys peregrina Zone is indicated by the extinction of $S$. peregrina. The Pliocene/Miocene boundary is marked by the first appearance of $L$. heteroporos. From the radiolarian occurrences, it follows that the Quaternary and Pliocene are only thinly represented by sediments, if at all. One or several sedimentation gaps or a very condensed sequence can be assumed between Core 1 and Sample 2,CC of Hole 468A.

Below the Quaternary-Pliocene beds, radiolarians restricted to the upper Miocene are rarely represented. Section 468-2-1 contains few specimens of Ommatartus antepenultimus, a species indicative of deposition in the early late Miocene. Section 468A-4-5 yielded Stichocorys peregrina abundantly and is assigned to the uppermost Miocene. Equivalent layers were found in Sample 468B-2,CC through Section 468B-3-4, which are again characterized by few specimens of $S$. peregrina and rare occurrences of $O$. antepenultimus. Only Section 4-1 and 


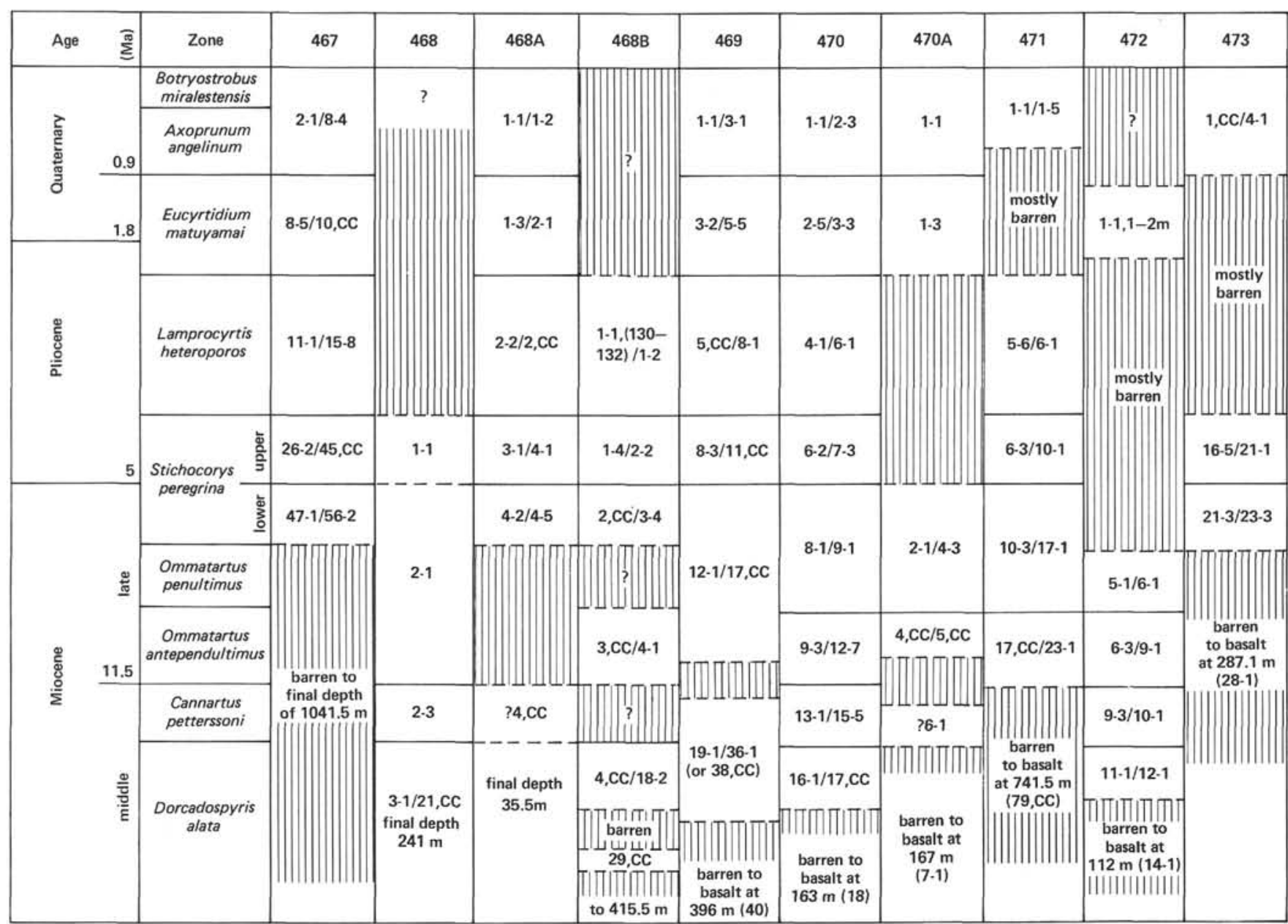

Figure 2. Radiolarian zonation of Neogene and Quaternary sedimentary depositions. After Kling (1973), the Pliocene/Quaternary boundary coincides with the base of the Eucyrtidium matuyamai Zone. According to the results of diatom (J. Barron, this volume) and nannofossil studies (D. Bukry, this volume), the Pliocene/Quaternary boundary presumably must be drawn within the lower part of the E. matuyamai Zone.

Table 1. Locations of Leg 63 Holes from which radiolarians were recovered.

\begin{tabular}{|c|c|c|c|c|c|}
\hline Hole & Latitude & Longitude & Location & $\begin{array}{l}\text { Water } \\
\text { Depth } \\
\text { (m) }\end{array}$ & $\begin{array}{l}\text { Cored } \\
\text { Section } \\
(\mathrm{m})\end{array}$ \\
\hline 467 & $33^{\circ} 50.97^{\prime} \mathrm{N}$ & $120^{\circ} 45.47^{\prime} \mathrm{W}$ & San Miguel Gap & 2127.8 & 1041.5 \\
\hline 468 & $32^{\circ} 37.03^{\prime} \mathrm{N}$ & $120^{\circ} 07.07^{\prime} \mathrm{W}$ & Patton Escarpment & 1849 & 241 \\
\hline $468 \mathrm{~A}, \mathrm{~B}$ & $32^{\circ} 37.41^{\prime} \mathrm{N}$ & $120^{\circ} 06.55^{\prime} \mathrm{W}$ & Patton Escarpment & 1737 & $\begin{array}{l}A=35.5 \\
B=415.5\end{array}$ \\
\hline 469 & $32^{\circ} 37.00^{\prime} \mathrm{N}$ & $120^{\circ} 32.90^{\prime} \mathrm{W}$ & $\begin{array}{l}\text { Foot of Patton } \\
\text { Escarpment }\end{array}$ & 3790 & 453.5 \\
\hline $470,470 \mathrm{~A}$ & $28^{\circ} 54.46^{\prime} \mathrm{N}$ & $117^{\circ} 31.11^{\prime} \mathrm{W}$ & East of Guadalupe Island & 3549 & $\begin{aligned} & 168 ; \\
\mathrm{A}= & 101.5\end{aligned}$ \\
\hline 471 & $23^{\circ} 28.93^{\prime} \mathrm{N}$ & $112^{\circ} 29.78^{\prime} \mathrm{W}$ & $\begin{array}{l}\text { Foot of continental } \\
\text { slope of Baja California }\end{array}$ & 3101 & 823 \\
\hline 472 & $23^{\circ} 00.35^{\prime} \mathrm{N}$ & $113^{\circ} 59.71^{\prime} \mathrm{W}$ & $\begin{array}{l}\text { Southwest of } \\
\text { Site } 471\end{array}$ & 3831 & 137.5 \\
\hline 473 & $20^{\circ} 57.92^{\prime} \mathrm{N}$ & $107^{\circ} 03.81^{\prime} \mathrm{W}$ & $\begin{array}{l}\text { Rivera plate south } \\
\text { of Tres Marias Island }\end{array}$ & 3249 & 287.5 \\
\hline
\end{tabular}




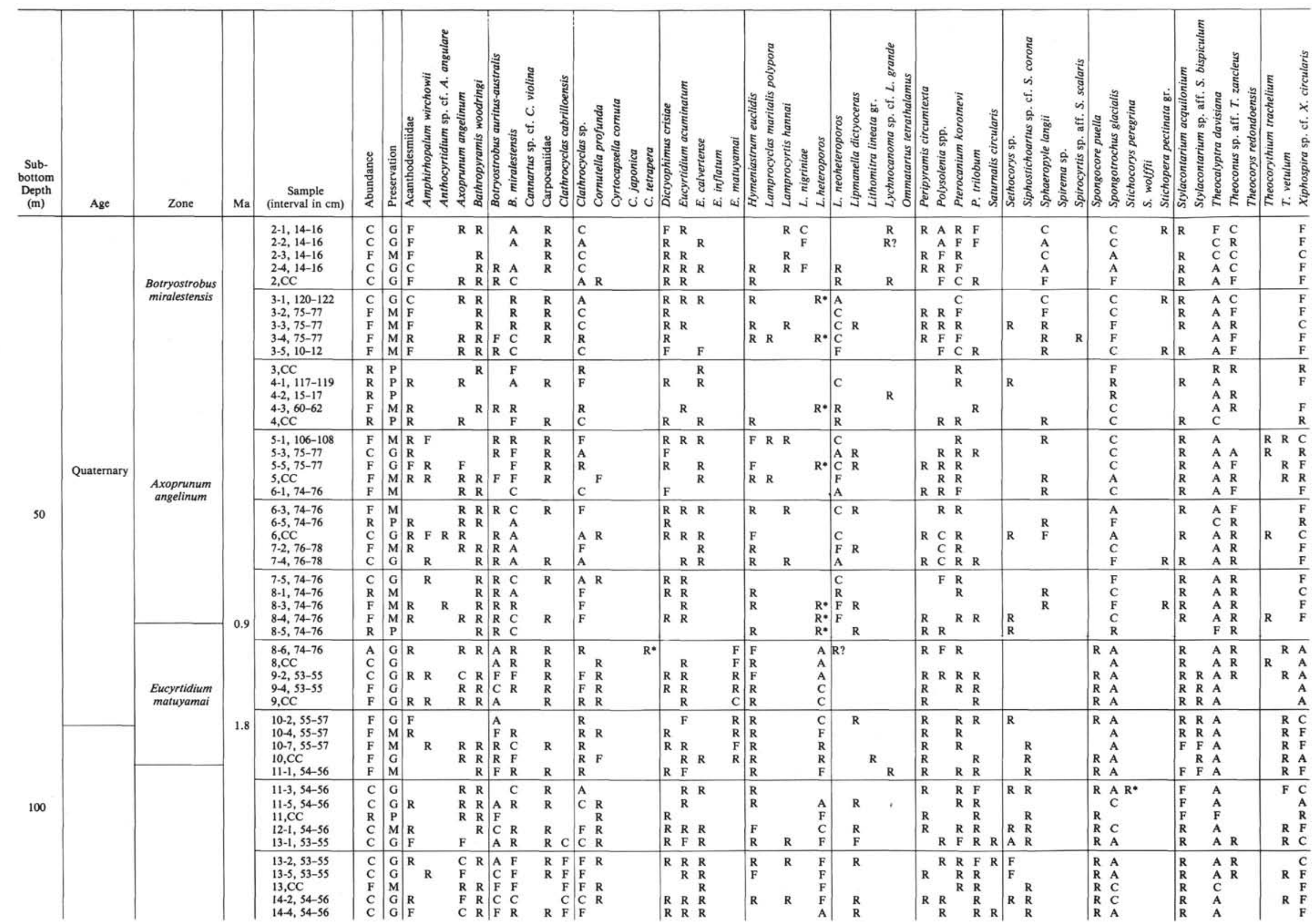




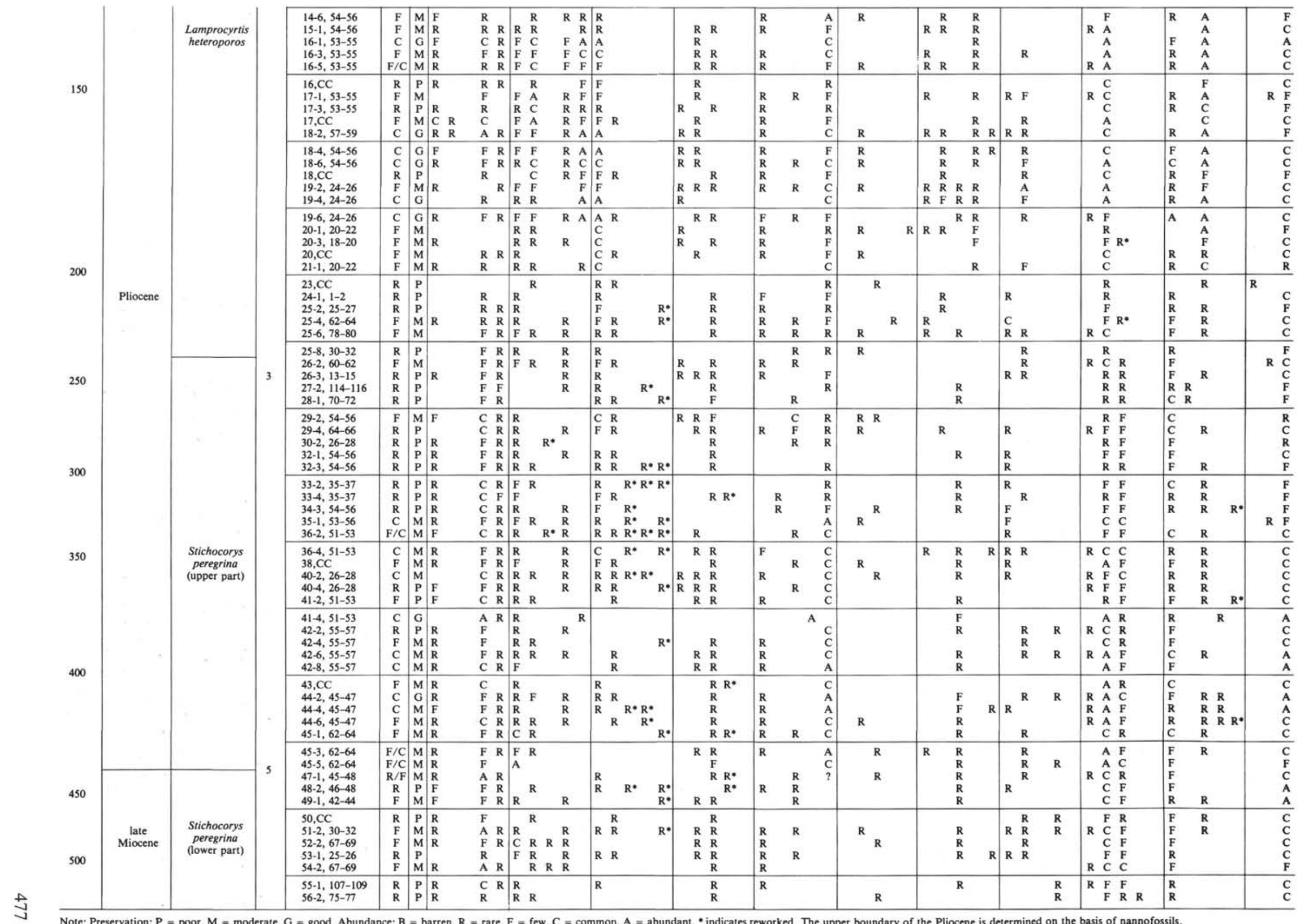


Table 3. Radiolarians from the Neogene sediments of Hole 468.

\begin{tabular}{|c|c|c|c|c|c|c|c|c|c|c|c|c|c|c|c|c|c|}
\hline $\begin{array}{l}\text { Sub- } \\
\text { bottom } \\
\text { Depth } \\
\text { (m) }\end{array}$ & Age & Zone & $\mathrm{Ma}$ & $\begin{array}{c}\text { Sample } \\
\text { (interval in } \mathrm{cm} \text { ) }\end{array}$ & 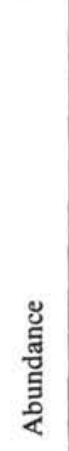 & 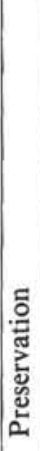 & 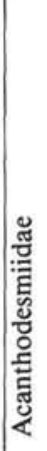 & 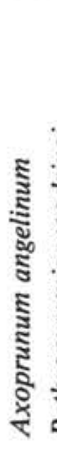 & 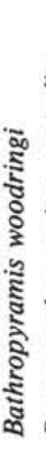 & 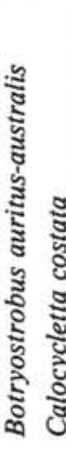 & 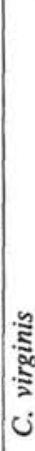 & 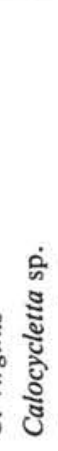 & 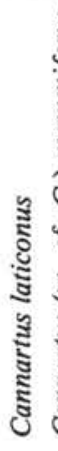 & 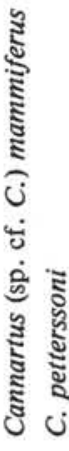 & 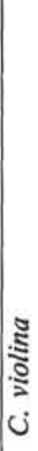 & 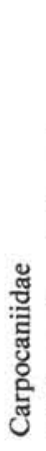 & 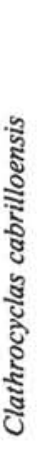 \\
\hline \multirow{6}{*}{50} & $\begin{array}{l}\text { early Pliocene } \\
\text { late Miocene }\end{array}$ & $\begin{array}{l}\text { S. peregrina, up. pt. } \\
\text { S. peregrina, low. pt. }\end{array}$ & 5 & $\begin{array}{l}1-1,90-92 \\
2-1,123-125\end{array}$ & $\begin{array}{l}\mathrm{R} \\
\mathrm{C}\end{array}$ & $\begin{array}{l}P \\
G\end{array}$ & A & $\begin{array}{l}\mathrm{R} \\
\mathrm{F}\end{array}$ & $\begin{array}{l}\mathbf{R} \\
\mathbf{R}\end{array}$ & $\mathrm{F}$ & & & & & & $\mathrm{R}$ & R \\
\hline & \multirow{7}{*}{$\begin{array}{l}\text { middle } \\
\text { Miocene }\end{array}$} & $\underbrace{\text { O. antepenultimus }}$ & 12.5 & $\begin{array}{l}2-3,5-7 \\
3-1,138-140 \\
3-3,140-142\end{array}$ & $\begin{array}{l}\text { C } \\
\text { A } \\
\text { F }\end{array}$ & $\begin{array}{l}G \\
G \\
M\end{array}$ & $\begin{array}{l}\text { A } \\
\text { A } \\
\text { C }\end{array}$ & $\begin{array}{l}\mathrm{R} \\
\mathrm{F} \\
\mathrm{C}\end{array}$ & $\begin{array}{l}\mathbf{R} \\
\mathrm{R}\end{array}$ & $\begin{array}{l}\mathrm{R} \\
\mathrm{R} \\
\mathrm{R}\end{array}$ & & $\mathbf{R}$ & $\begin{array}{l}\mathbf{R} \\
\mathrm{R}\end{array}$ & $\mathrm{F}$ & & $\mathbf{R}$ & R \\
\hline & & \multirow{7}{*}{$\begin{array}{l}\text { Dorcadospyris } \\
\text { alata }\end{array}$} & & $\begin{array}{l}3-5,80-82 \\
4-1,40-42 \\
4-3,40-42 \\
4-5,40-42 \\
5-1,140-142\end{array}$ & $\begin{array}{l}\text { F } \\
\text { F } \\
\text { F } \\
\text { A } \\
\text { C }\end{array}$ & $\begin{array}{l}M \\
M \\
M \\
G \\
G\end{array}$ & $\begin{array}{l}\text { C } \\
\text { C } \\
\text { C } \\
\text { A } \\
\text { C }\end{array}$ & $\begin{array}{l}\mathrm{C} \\
\mathrm{F} \\
\mathrm{C} \\
\mathrm{C} \\
\mathrm{C}\end{array}$ & $\begin{array}{l}\mathbf{R} \\
\mathrm{R} \\
\mathbf{R} \\
\mathrm{R}\end{array}$ & $\begin{array}{l}F \\
F \\
F \\
F \\
F\end{array}$ & & & $\begin{array}{l}\mathrm{F} \\
\mathrm{F} \\
\mathrm{R} \\
\mathrm{F} \\
\mathrm{R}\end{array}$ & $\begin{array}{l}\mathrm{R} \\
\mathrm{R}\end{array}$ & & $\begin{array}{l}\mathbf{R} \\
\mathbf{R}\end{array}$ & $\begin{array}{l}R \\
R \\
R \\
R\end{array}$ \\
\hline & & & & $\begin{array}{l}5-3,133-135 \\
5-5,118-120 \\
6-1,18-20 \\
6-3,18-20 \\
6-5,18-20\end{array}$ & $\begin{array}{l}F \\
F \\
F \\
F \\
F\end{array}$ & $\begin{array}{l}\mathrm{M} \\
\mathrm{M} \\
\mathrm{M} \\
\mathrm{M} \\
\mathrm{M}\end{array}$ & $\begin{array}{l}\mathrm{C} \\
\mathrm{F} \\
\mathrm{F} \\
\mathrm{C} \\
\mathrm{F}\end{array}$ & $\begin{array}{l}\mathrm{C} \\
\mathrm{C} \\
\mathrm{C} \\
\mathrm{C} \\
\mathrm{C}\end{array}$ & $\begin{array}{l}\mathbf{R} \\
\mathrm{R} \\
\mathbf{R} \\
\mathrm{R}\end{array}$ & $\begin{array}{l}\mathrm{F} \\
\mathrm{F} \\
\mathrm{R} \\
\mathrm{R} \\
\mathrm{R}\end{array}$ & & $\begin{array}{l}\mathbf{R} \\
\mathrm{R}\end{array}$ & $\begin{array}{l}\mathrm{R} \\
\mathrm{F} \\
\mathrm{F} \\
\mathrm{F} \\
\mathrm{R}\end{array}$ & $\begin{array}{l}\mathrm{R} \\
\mathrm{R}\end{array}$ & & $\begin{array}{l}\mathbf{R} \\
\mathbf{R}\end{array}$ & $\begin{array}{l}R \\
R \\
R \\
R \\
R\end{array}$ \\
\hline & & & & $\begin{array}{l}7-2,100-102 \\
7-4,70-72 \\
7-6,70-72 \\
8-1,38-40 \\
8-3,38-40\end{array}$ & $\begin{array}{l}\mathrm{F} \\
\mathrm{F} \\
\mathrm{R} \\
\mathrm{F} \\
\mathrm{F}\end{array}$ & $\begin{array}{l}\mathrm{M} \\
\mathrm{M} \\
\mathrm{M} \\
\mathrm{M} \\
\mathrm{M}\end{array}$ & $\begin{array}{l}\mathrm{C} \\
\mathrm{R} \\
\mathrm{C} \\
\mathrm{C} \\
\mathrm{C}\end{array}$ & $\begin{array}{l}\text { F } \\
\text { F } \\
\text { C } \\
\text { C } \\
\text { F }\end{array}$ & $\begin{array}{l}\mathrm{R} \\
\mathrm{R} \\
\mathrm{R} \\
\mathrm{R}\end{array}$ & $\begin{array}{l}\mathrm{F} \\
\mathrm{R} \\
\mathrm{R} \\
\mathrm{R}\end{array}$ & & $\begin{array}{l}\mathbf{R} \\
\mathbf{R} \\
\mathrm{R} \\
\mathrm{C}\end{array}$ & $\begin{array}{l}\mathrm{R} \\
\mathrm{F} \\
\mathrm{R} \\
\mathrm{F} \\
\mathrm{C}\end{array}$ & & & $\begin{array}{l}\mathrm{R} \\
\mathrm{R} \\
\mathrm{F} \\
\mathrm{R} \\
\mathrm{F}\end{array}$ & $\begin{array}{l}\mathrm{F} \\
\mathrm{R} \\
\mathrm{R} \\
\mathrm{R}\end{array}$ \\
\hline & & & & $\begin{array}{l}9-1,60-62 \\
9-3,60-62 \\
9-5,60-62 \\
10-1,66-68 \\
10-3,66-68\end{array}$ & $\begin{array}{c}\mathrm{F} \\
\mathrm{R} \\
\mathrm{F} / \mathrm{C} \\
\mathrm{F} \\
\mathrm{R}\end{array}$ & $\begin{array}{l}\mathrm{M} \\
\mathrm{P} \\
\mathrm{M} \\
\mathrm{M} \\
\mathrm{P}\end{array}$ & $\begin{array}{l}\mathrm{F} \\
\mathrm{F} \\
\mathrm{F} \\
\mathrm{C} \\
\mathrm{F}\end{array}$ & $\begin{array}{l}\mathrm{R} \\
\mathrm{F} \\
\mathrm{F} \\
\mathrm{R} \\
\mathrm{R}\end{array}$ & $\begin{array}{l}\mathbf{R} \\
\mathrm{R}\end{array}$ & $\begin{array}{l}\mathbf{R} \\
\mathbf{R}\end{array}$ & & $\begin{array}{l}\mathrm{C} \\
\mathrm{R} \\
\mathrm{A} \\
\mathrm{F} \\
\mathrm{R}\end{array}$ & $\begin{array}{l}\mathrm{F} \\
\mathrm{R} \\
\mathrm{A} \\
\mathrm{F} \\
\mathrm{F}\end{array}$ & $\begin{array}{l}\mathrm{R} \\
\mathrm{R} \\
\mathrm{R} \\
\mathrm{R}\end{array}$ & & $\begin{array}{l}\mathrm{F} \\
\mathrm{R} \\
\mathrm{F} \\
\mathrm{F} \\
\mathrm{R}\end{array}$ & $\begin{array}{l}R \\
R\end{array}$ \\
\hline \multirow[t]{2}{*}{$\begin{array}{l}100 \\
150\end{array}$} & & & & $\begin{array}{l}11-1,90-92 \\
13-1,75-77 \\
17, C C \\
18-1,56-58 \\
18-3,56-58\end{array}$ & $\begin{array}{l}F \\
R \\
R \\
F \\
F\end{array}$ & $\begin{array}{l}\mathrm{M} \\
\mathrm{P} \\
\mathrm{P} \\
\mathrm{P} \\
\mathrm{P}\end{array}$ & $\begin{array}{l}\mathrm{F} \\
\mathrm{F} \\
\mathrm{R} \\
\mathrm{F}\end{array}$ & $\begin{array}{l}\mathrm{R} \\
\mathrm{R} \\
\mathrm{R} \\
\mathrm{R} \\
\mathrm{R}\end{array}$ & R & $\begin{array}{l}\mathrm{R} \\
\mathrm{R}\end{array}$ & $\begin{array}{l}\mathrm{R} \\
\mathrm{R} \\
\mathrm{R}\end{array}$ & $\begin{array}{l}\mathrm{F} \\
\mathrm{R}\end{array}$ & $\begin{array}{l}\mathrm{R} \\
\mathrm{R} \\
\mathrm{R}\end{array}$ & $\begin{array}{l}\mathrm{R} \\
\mathrm{R} \\
\mathrm{R}\end{array}$ & R & $\begin{array}{l}R \\
R \\
R \\
F \\
R\end{array}$ & \\
\hline & & & & $\begin{array}{l}18-5,51-53 \\
18, \mathrm{CC} \\
19, \mathrm{CC} \\
21-1,9-11 \\
21, \mathrm{CC}\end{array}$ & $\begin{array}{l}\mathrm{F} \\
\mathrm{R} \\
\mathrm{R} \\
\mathrm{F} \\
\mathrm{R}\end{array}$ & $\begin{array}{l}\mathrm{P} \\
\mathrm{P} \\
\mathrm{P} \\
\mathrm{P} \\
\mathrm{P}\end{array}$ & $\begin{array}{l}\text { F } \\
\text { R } \\
\text { F }\end{array}$ & $\begin{array}{l}\mathrm{R} \\
\mathrm{R} \\
\mathrm{R}\end{array}$ & & $\mathrm{R}$ & $\begin{array}{l}\mathrm{R} \\
\mathrm{F}\end{array}$ & & & $\begin{array}{l}\mathrm{R} \\
\mathrm{R} \\
\mathrm{R} \\
\mathrm{R} \\
\mathrm{R}\end{array}$ & R & $\begin{array}{l}\mathrm{R} \\
\mathrm{R}\end{array}$ & \\
\hline \multirow{2}{*}{$\begin{array}{l}200 \\
212.5\end{array}$} & & & \multirow{2}{*}{16.5} & $23, \mathrm{CC}$ & R & $\mathrm{P}$ & & & & & & & & & & & \\
\hline & $\begin{array}{c}\text { early } \\
\text { Miocene }\end{array}$ & $\begin{array}{c}\text { Calocycletta } \\
\text { costata }\end{array}$ & & & & & & & & & & & & & & & \\
\hline
\end{tabular}

Note: See the note in Table 2 for key to the symbols.

Sample 3,CC of Hole 468B could be placed in the lower upper Miocene $O$. antepenultimus Zone, according to the presence of rare to few specimens of Ommatartus hughesi and $O$. antepenultimus. It is obvious, then, that a part of the upper Miocene is not represented by sediments. At Holes 468 and 468B, radiolarian assemblages of the $O$. antepenultimus Zone could be identified; fossils of the upper upper Miocene S. peregrina Zone were encountered in Holes 468A and 468B. Radiolarian assemblages of the $O$. penultimus Zone could not be recognized in the Site 468 holes; radiolarians of the lower $S$. peregrina Zone are lacking in Hole 468; those of the $O$. antepenultimus Zone have not been found in Hole 468A. It is probable, therefore, that the upper Miocene sediments constitute a rather thin, condensed (or incomplete) succession.

Only part of the middle Miocene seems to be well represented by a rather thick succession of sediments at 
Table 3. (Continued).

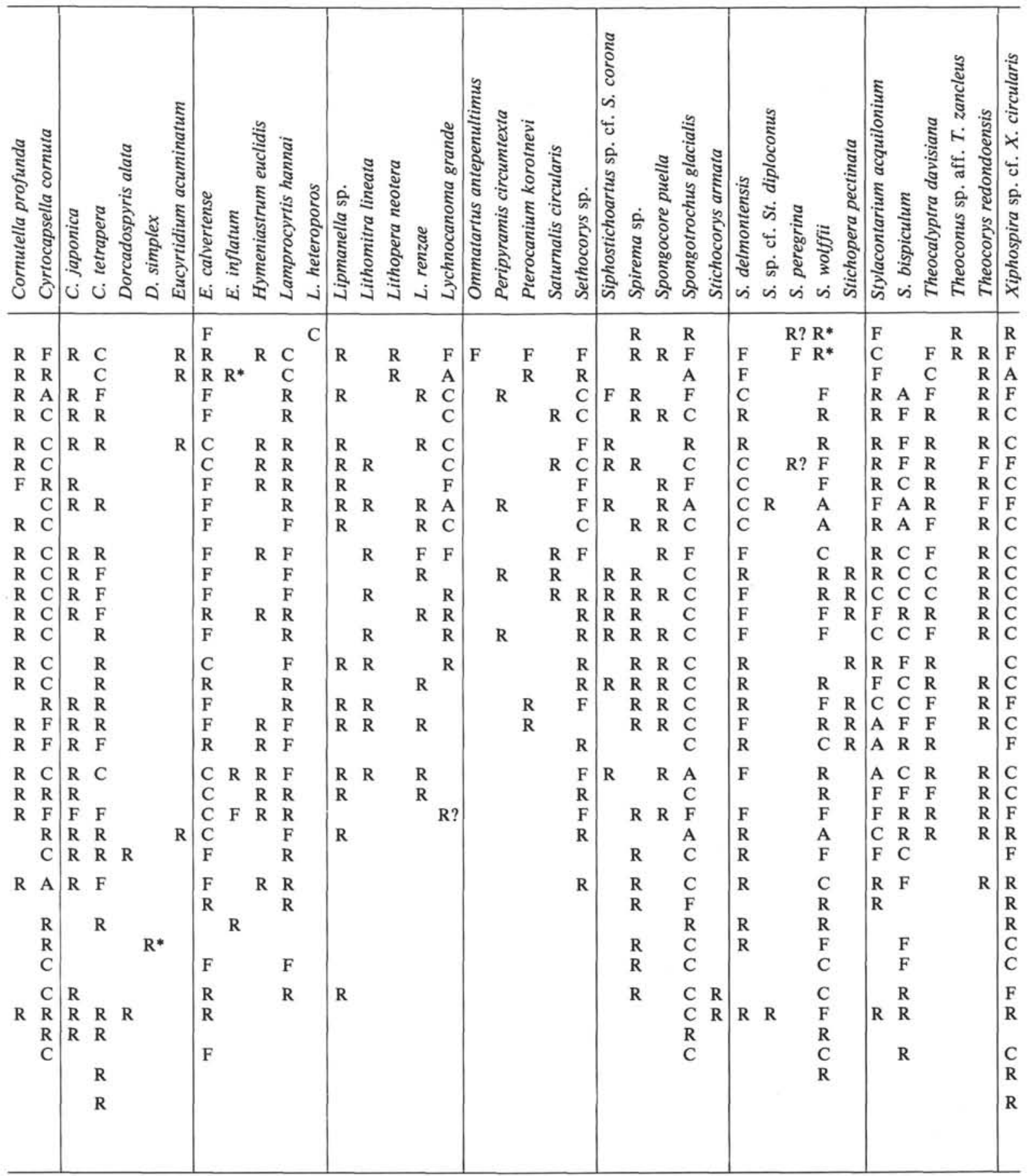

this site, because the radiolarian assemblage of the upper middle Miocene Cannartus petterssoni Zone, especially C. petterssoni, was not encountered in Holes 468A and $\mathrm{B}$. In Hole $468, C$. petterssoni is present in Section 2-3, only; the lower to middle middle Miocene Dorcadospyris alata Zone begins with Section 3-1 and ends possibly with Sample 18,CC. In its lower part, the middle Miocene succession is characterized by rare occurrences of Cannartus mammiferus, which is progressively replaced by rare to abundant individuals of Can- nartus laticonus in the upper part. Besides mainly rare occurrences of Eucyrtidium inflatum and Lithopera renzae, which are assumed to be diagnostic for middle Miocene, various species of Cyrtocapsella and Stichocorys (except $S$. peregrina) are rare to abundant. The succession below Core 18 of Hole 468 cannot be assigned securely either to the lower middle or upper lower Miocene by means of radiolarians.

Besides rare, sporadic occurrences of $D$. alata, no radiolarians are present that precisely mark the lower 
Table 4. Radiolarians from the Neogene and Quaternary sediments of Holes 468A and 468B.

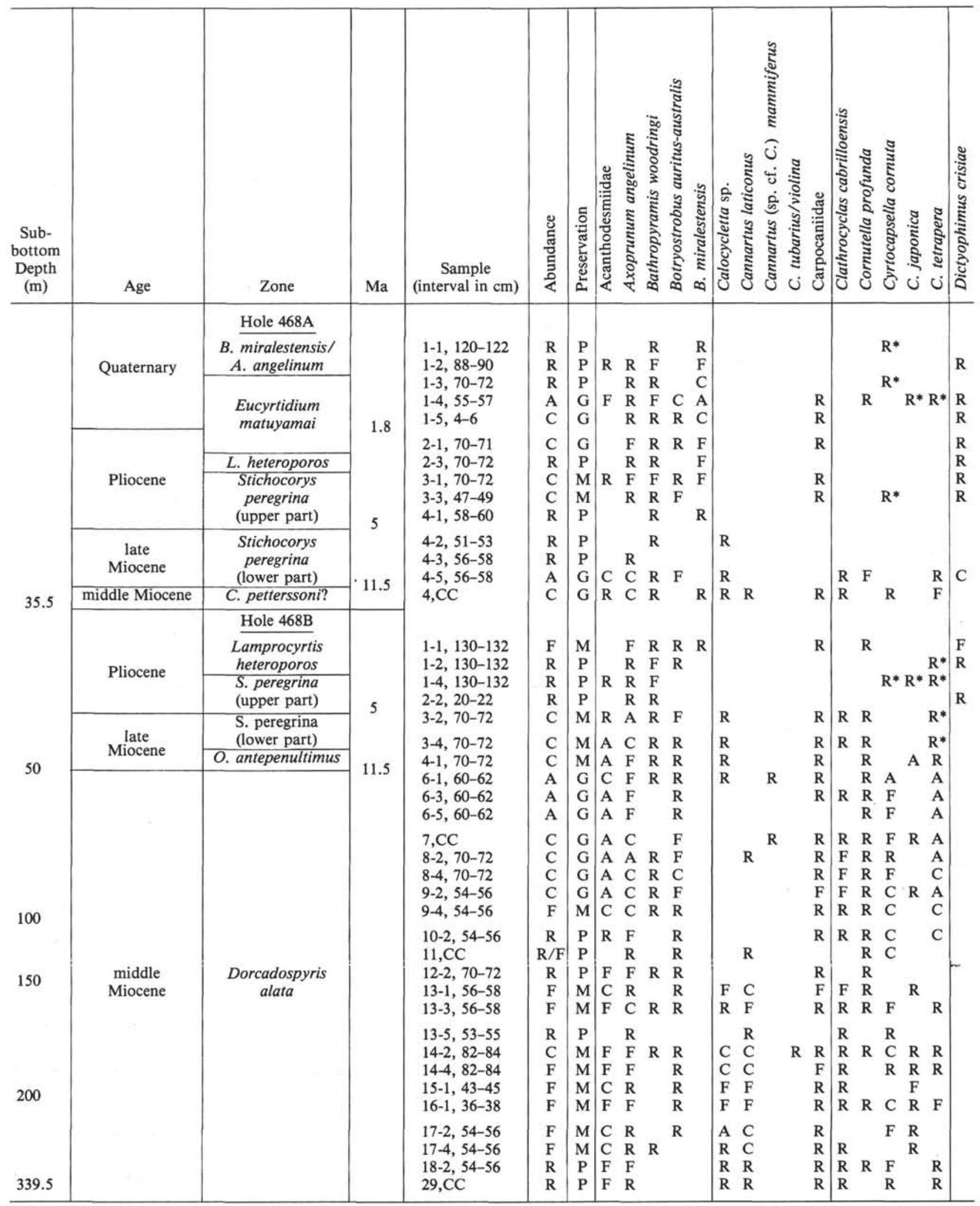

Note: See Table 2 for a key to the symbols. 


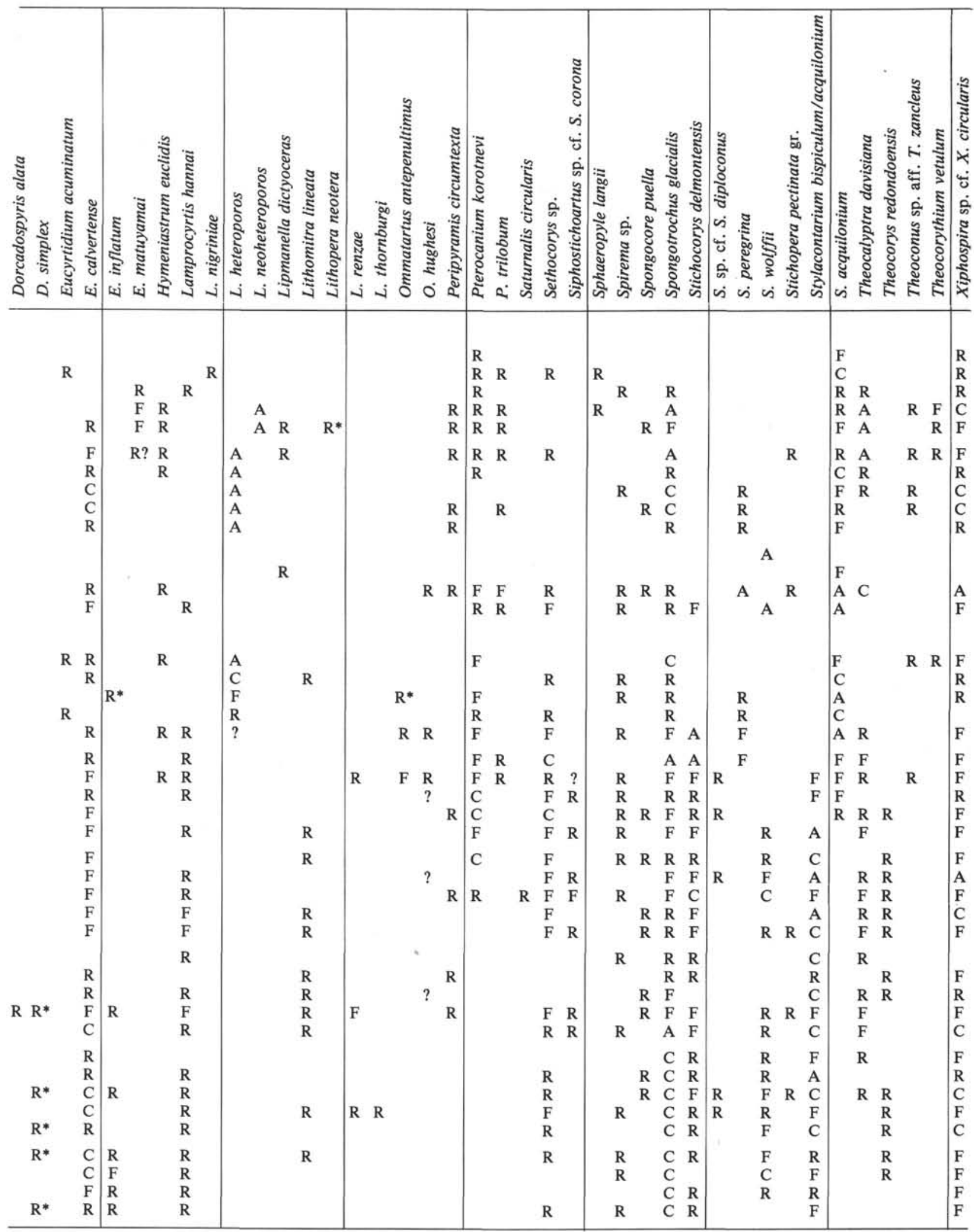


boundary of the middle Miocene. On the other hand, mainly lower Miocene species, such as Calocycletta costata, C. virginis, and Dorcadospyris simplex, are rare to common in Cores 17 through 21 (Hole 468). According to the results of diatom research, Sample 21,CC still contains middle Miocene species. Therefore the lower Miocene radiolarians are probably reworked.

In the region of Sites 467 and 468, the Quaternary radiolarian assemblages mainly consist of cold-water species. Site 468 differs from Site 467 , however, in that some warm-water species (Amphirhopalum ypsilon, Theocorythium vetulum) joined the North Pacific assemblage.

\section{Site 469}

At Site 469 on the foot of Patton Escarpment, a single hole was continuously cored to a total depth of 453.5 meters, the lower 59.5 meters in the basement. It contains abundant to rare middle Miocene through Quaternary radiolarians of poor to good preservation (Cores 1-25). Very rare and poorly preserved lower middle Miocene radiolarians occur sporadically in Cores 30 , 35,36 , and 38 , immediately above the basement. The poor remains of siliceous microfossils in some cores of the lower middle Miocene section suggest that the absence or presence of radiolarians in that region is due to diagenesis rather than to the primary lack of siliceous skeletons. Table 5 lists radiolarians from the Neogene and Quaternary sediments of Hole 469.

The Quaternary sediments of Hole 469 yielded radiolarian assemblages containing northeastern Pacific cold-water species as well as less numerous equatorial warm-water species; Kling's (1973) zonation was applicable. Cores 1 through 3 , Section 1 can be assigned to the upper Pleistocene Axoprunum angelinum Zone, as indicated by the rare to abundant presence of Lamprocyrtis nigriniae and Lamprocyrtis neoheteroporos and the absence of Eucyrtidium matuyamai and Lamprocyrtis heteroporos. The upper Pleistocene interval contains sporadically older radiolarians, such as different species of Cyrtocapsella, E. matuyamai, L. heteroporos, and Stichocorys peregrina, which must be considered to be reworked. Characterized by the rare to common occurrence of E. matuyamai and L. neoheteroporos in the upper part and $L$. heteroporos in the lowermost part, Section 3-2 through Section 5-5 can be placed into the lower Pleistocene/uppermost Pliocene E. matuyamai Zone.

Deposition in the late Pliocene ( $L$. heteroporos Zone) is indicated for Sample 5,CC through Section 8-1 by the few to abundant presence of $L$. heteroporos and the absence of E. matuyamai and Stichocorys peregrina. The association of common to abundant individuals of $L$. heteroporos and rare to common occurrences of $S$. peregrina suggest that Section 8-3 through Sample $11, \mathrm{CC}$ (S. peregrina Zone, upper part) were deposited in the early Pliocene. The boundary between Miocene and Pliocene seems to be marked by a sudden and abundant appearance of $L$. heteroporos.

Section 12-1 through Sample 17,CC are upper Miocene. The fact that this interval contains few to abun- dant $S$. peregrina but lacks Ommatartus antepenultimus and, except for Sample 17,CC, Ommatartus penultimus suggests that the lower part of the upper Miocene succession (O. antepenultimus and $O$. penultimus Zones) is partly or totally missing at Site 469 .

Cannartus petterssoni has not been found below Core 17. This indicates that the upper middle Miocene C. petterssoni Zone is either not represented at all or represented by a condensed succession only. Cores 19 through 30 are distinguished by the presence of Cannartus laticonus, Cannartus mammiferus, various species of Cyrtocapsella, Stichocorys delmontensis, Stichocorys wolffii a.o., which suggests deposition during the early middle Miocene (Dorcadospyris alata Zone). The poor assemblages gained from Cores 32 through 36 were probably deposited in the early middle Miocene. A definite conclusion cannot be drawn, regarding the ages of Cores 38 through 39. Sample 38,CC yielded Cyrtocapsella tetrapera and Cannartus violina. Available evidence suggests that $C$. violina is restricted to the lower Miocene. Consequently it follows that Samples $38, \mathrm{CC}$ and 39, CC are either lower middle Miocene with C. violina being reworked or upper lower Miocene with C. violina as an authochthonous fossil.

According to the radiolarian zonation, the Quaternary and Pliocene seem to be rather entirely represented at Site 469 , perhaps with the exception of the upper Quaternary Botryostrobus miralestensis Zone. Upper and middle Miocene, however, seem to be only incompletely represented by sediments, because the assemblages with $O$. penultimus, $O$. antepenultimus, and $C$. petterssoni are partly or totally missing. The Pliocene and Quaternary radiolarian zones introduced by Kling (1973) are restricted to the cold-water regions of the North Pacific; they are associated with few specimens of equatorial species in Cores 1 through 8 at Site 469, such as the Pliocene-Quaternary species Amphirhopalum ypsilon, Ommatartus tetrathalamus, Spongaster tetras, and Theocorythium vetulum. The lower Pliocene and Miocene assemblages are for the most part composed of warm-water species, the number of which decreases from Miocene toward the lower Pliocene. The total lack of the equatorial lower middle Miocene Dorcadospyris alata may be considered an indication of cold-water influence.

\section{Site 470}

East of Guadalupe Island, $8 \mathrm{~km}$ south-southwest of the Experimental Mohole, Hole 470 was continuously cored to basalt at 167 meters. Hole $470 \mathrm{~A}$ was cored from 47.5 to 95 meters and from 161.5 to 168 meters in sediment, then continuously cored in basalt to 215.5 meters. Few to abundant middle Miocene through Quaternary radiolarians of moderate to good preservation were recovered from Cores 7 through 17 in Hole 470 (lower Pliocene through middle Miocene) and from Core 1, Section 3 through Core 5 in Hole 470A (lower Quaternary and upper Miocene). Core 1, Section 3 through Core 6 of Hole 470 and Core 1, Section 1 of Hole $470 \mathrm{~A}$ yielded rare, poorly preserved radiolarians. Sections 1-1, 4-1, 5-1, and 18-2 of Hole 470 are barren. 
Tables 6 and 7 list radiolarians from the Neogene and Quaternary sediments of Holes 470 and $470 \mathrm{~A}$, respectively.

Except for Section 2-5, the upper layers of Hole 470 from Cores 1 through 6 are so poor in radiolarians that only incomplete zonal classification is possible. Section 2-5 must be assigned to the lower Pleistocene-upper Pliocene Eucyrtidium matuyamai Zone, because it contains rare to few individuals of the zone fossil and of Lamprocyrtis neoheteroporos and $L$. heteroporos as well as rare members of the equatorial species $\mathrm{Om}$ matartus tetrathalamus, Spongaster tetras, and Theocorythium vetulum. A very thin cover of Quaternary sediments was encountered at Site 470A. Section 1 of Core 1 contains nondiagnostic radiolarians only and is tentatively assumed to have been deposited in the late Quaternary. Sediments from below this section can be assigned to the lower Quaternary E. matuyamai Zone, because they yielded both Lamprocyrtis neoheteroporos and $L$. heteroporos.

There are enough equatorial species in the Pliocene and Miocene cores of Hole 470 to permit recognition of equatorial zones. The first rare appearance of $L$. heteroporos, the last occurrences of S. peregrina, and the absence of the diagnostic Pleistocene and Miocene species indicate that deposition took place in the early Pliocene (upper part of S. peregrina Zone, Core 6, Section 2 through Core 7 of Hole 470). The Miocene/Pliocene boundary is placed between Cores 8 and 7 below the first appearance of $L$. heteroporos, which follows in that region immediately above the last presence of $\mathrm{Om}$ matartus penultimus. In Hole 470A, the upper part of the $S$. peregrina Zone could not be recognized.

The upper Miocene lower part of the S. peregrina Zone cannot be separated from the underlying $\mathrm{Om}$ matartus penultimus Zone. Both of them comprise Section 8-1 through Section 9-1 of Hole 470 and Section 2-1 through Section 4-3 of Hole 470A. They are distinguished by few to abundant occurrences of $S$. peregrina and by rare individuals of $O$. penultimus. Besides several nondiagnostic radiolarians, there are rare to abundant occurrences of Lithopera neotera and Stichocorys wolffii, which are presumably reworked, according to present knowledge. Stichocorys delmontensis joins the assemblage in the lower part of the uppermost Miocene section.

According to Riedel and Sanfilippo (1978) and in accordance with Kling (1973), the O. antepenultimus Zone is defined by the evolutionary bottom and the morphotypic top of $O$. hughesi. Consequently, the lower boundary of the lower upper Miocene $O$. antepenultimus Zone can tentatively be placed between the main occurrences of $O$. hughesi and Cannartus petterssoni in Hole 470 (either below Section 12-1 or below Section 12-7). Various species of Cyrtocapsella, Lithopera, Stichocorys delmontensis, and $S$. wolffii complete the radiolarian assemblage of the $O$. antepenultimus Zone. The succession of Hole 470A ends with Core 6 in the lower upper Miocene $O$. antepenultimus Zone, immediately above basalt.

The boundary between middle and late Miocene is thus defined by the first appearance of the typical $O$. hughesi (below Section 12-7). The transition between $C$. petterssoni and $O$. hughesi, however, cannot always be clearly recognized, and it is sometimes difficult to separate one species from the other. At Site 470, the upper middle Miocene $C$. petterssoni Zone comprises Section 13-1 through Section 15-5. Its lower boundary is defined by the first appearance of $C$. petterssoni, which is associated with Cannartus laticonus, various species of Cyrtocapsella, Lithopera, and Stichocorys.

The lowermost part of the succession encountered at Site 470 (Sample 15,CC through Core 17) contains few to abundant, well-preserved radiolarians of the lower middle Miocene Dorcadospyris alata Zone: C. laticonus, various species of Cyrtocapsella, Lithopera, and Stichocorys etc., without $C$. petterssoni. Core 18, immediately overlying the basalt, is barren.

The Pliocene and Miocene radiolarian assemblages of Site 470 are for the most part composed of equatorial warm-water species. Nevertheless, as at Site 469 , the total lack of the equatorial middle Miocene Dorcadospyris alata suggests that a certain cold-water influence prevailed during that time. As far as we can conclude from the sparse evidence, the Quaternary assemblage consists of mixed cold- and warm-water species.

\section{Site 471}

Hole 471 was drilled on the distal portion of a deepsea fan west of the foot of the continental slope off Baja California. Hole 471 was continuously cored to the top of the diabase at 741.5 meters.

The interval between Section 1-5 and Section 5-4 is barren at Site 471 . Sections 3 and 5 of Core 1 contain only rare, nondiagnostic radiolarians, and Section 1 yielded with Amphirhopalum ypsilon and ?Ommatartus tetrathalamus - two species of the Quaternary-Pliocene. The latter section (5-4) does contain only rare individuals of Stichocorys peregrina and can be tentatively assigned to the Quaternary. The Quaternary/Pliocene boundary can be placed on top of the youngest fossiliferous layers (Section 5-6) with Lamprocyrtis heteroporos. It must be emphasized, however, that the true position of that boundary at Site 471 cannot be found by means of radiolarians. Table 8 lists radiolarians from the Neogene and Quaternary sediments of Hole 471.

Deposition in the late Pliocene is indicated for Section 5-6 through Section 6-1 by rare occurrences of $L$. heteroporos and the absence of Eucyrtidium matuyamai; otherwise there are only rare, nondiagnostic radiolarians. The extinction of Stichocorys peregrina marks the boundary between the upper Pliocene $L$. heteroporos Zone and the lower Pliocene $S$. peregrina Zone (upper part), which comprises the interval between Section 6-3 and Section 10-1. Mostly few to common, moderately to well-preserved radiolarians are significant for 
Table 5. Radiolarians from the Neogene and Quaternary sediments of Hole 469.

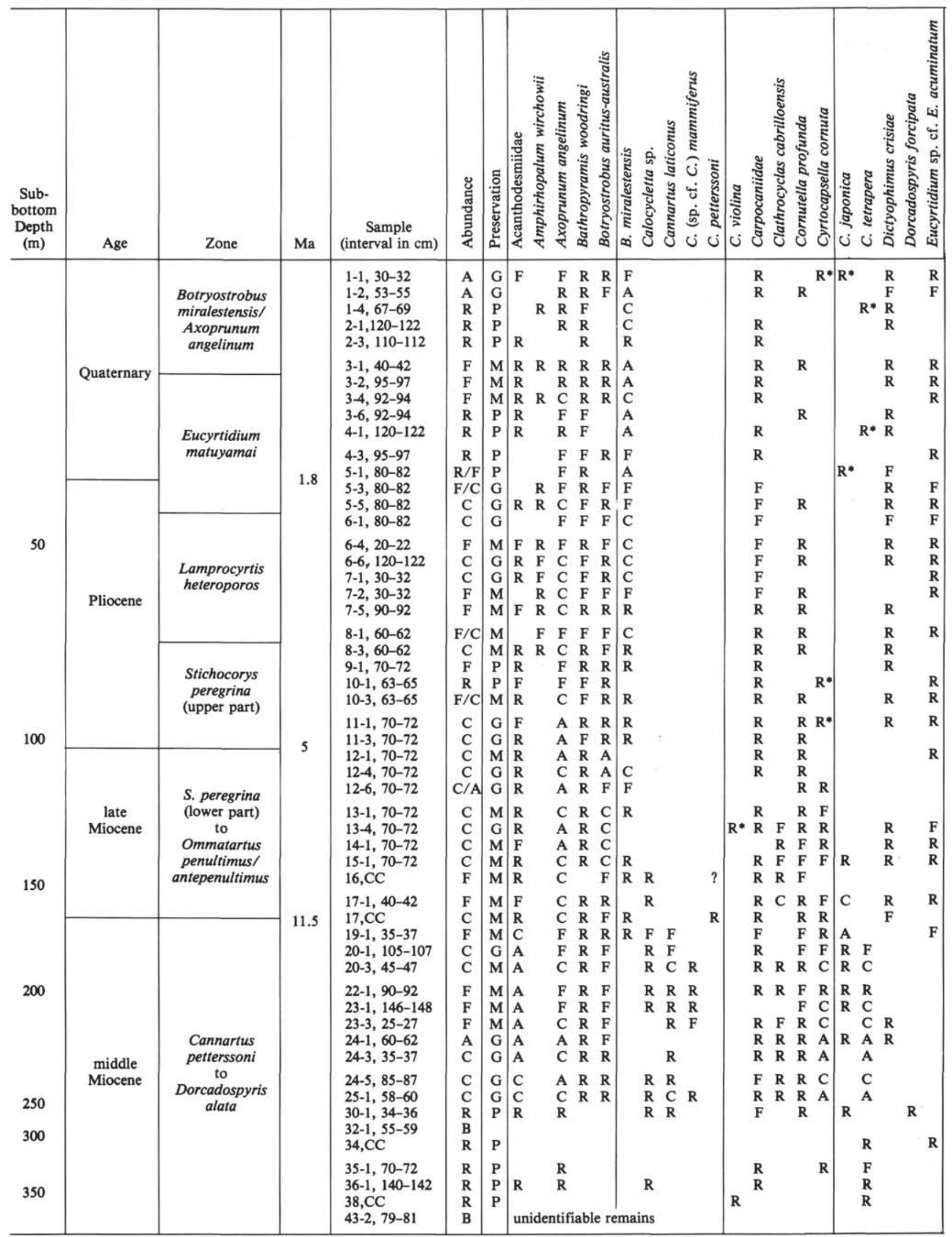

Note: See Table 2 for a key to the symbols. 
Table 5. (Continued).

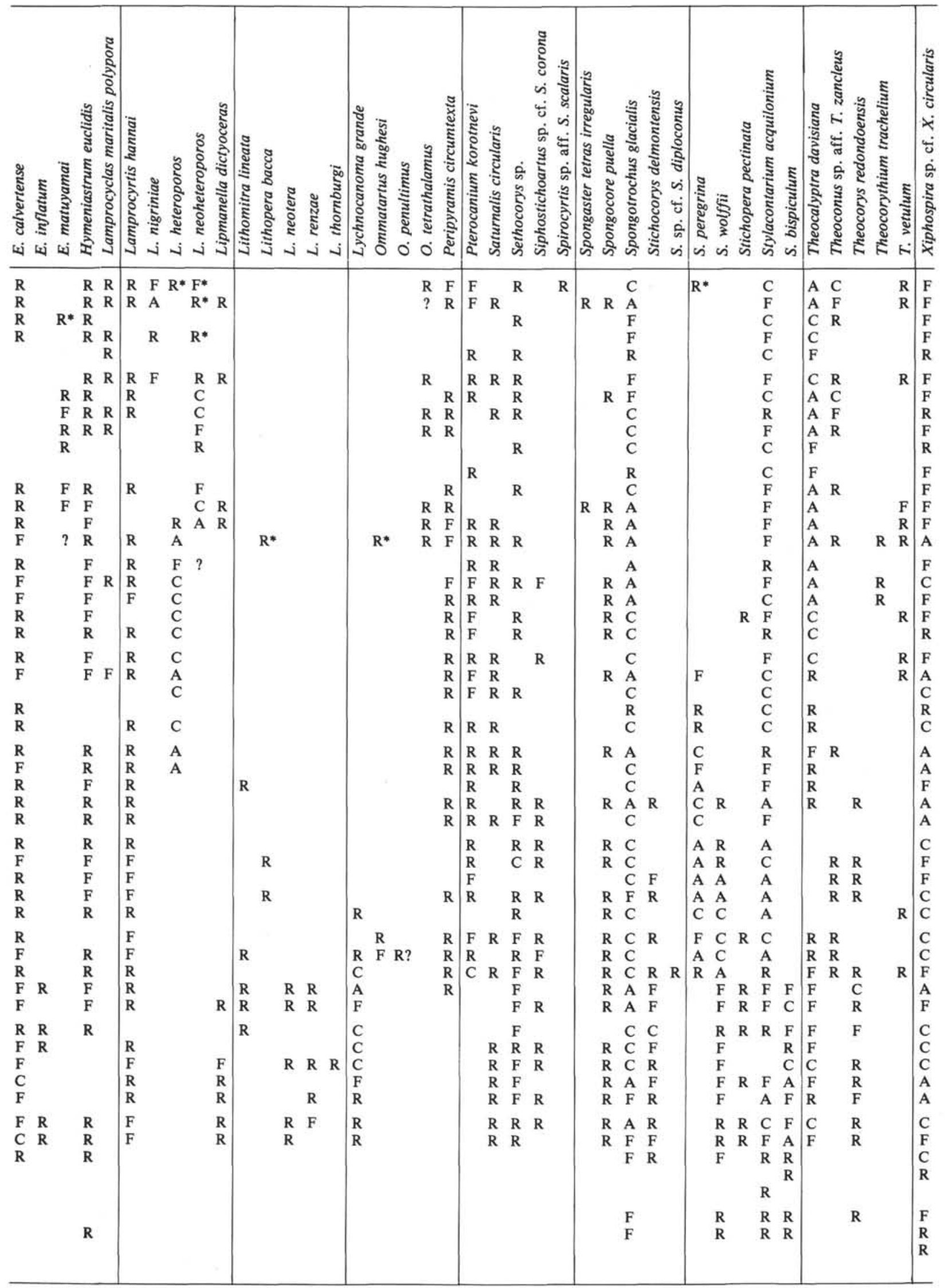


Table 6. Radiolarians from the Neogene and Quaternary sediments of Hole 470 .

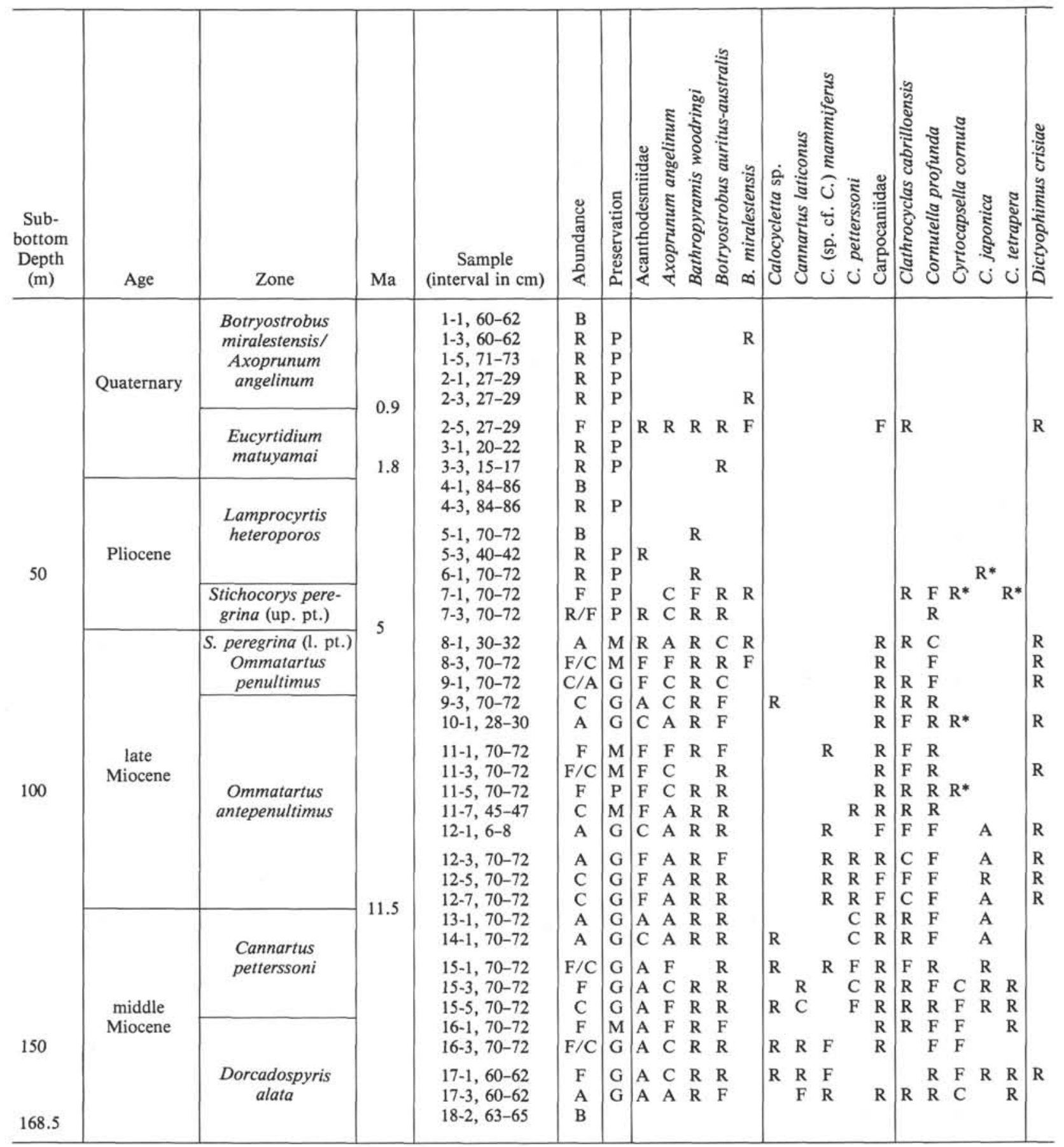

Note: See Table 2 for a key to the symbols.

the lower Pliocene succession. Its lower limit is indicated by the first appearance of $L$. heteroporos. Besides $S$. peregrina, with rare to abundant occurrences, $\mathrm{Om}$ matartus penultimus is another rare to common species that survived the Miocene/Pliocene boundary.

The upper Miocene cores of Hole 471 contain a radiolarian assemblage that is rather rich in species and almost exclusively composed of warm-water species. The equatorial zonation is therefore applicable. Deposition in the late late Miocene (lower part of the $S$. peregrina Zone) is suggested for Section 10-3 through Section $17-1$ by the presence of $S$. peregrina, $S$. delmontensis, $S$. wolffii, $O$. penultimus, and $O$. antepenultimus and by the absence of $L$. heteroporos. Separating the upper upper Miocene $S$. peregrina Zone from the middle upper Miocene $O$. penultimus Zone is not possible at Site 471 , because the first appearances of $S$. peregrina and $O$. penultimus nearly coincide, and because the occurrences of $S$. delmontensis and $S$. peregrina considerably overlap. There is no radiolarian 
Table 6. (Continued).

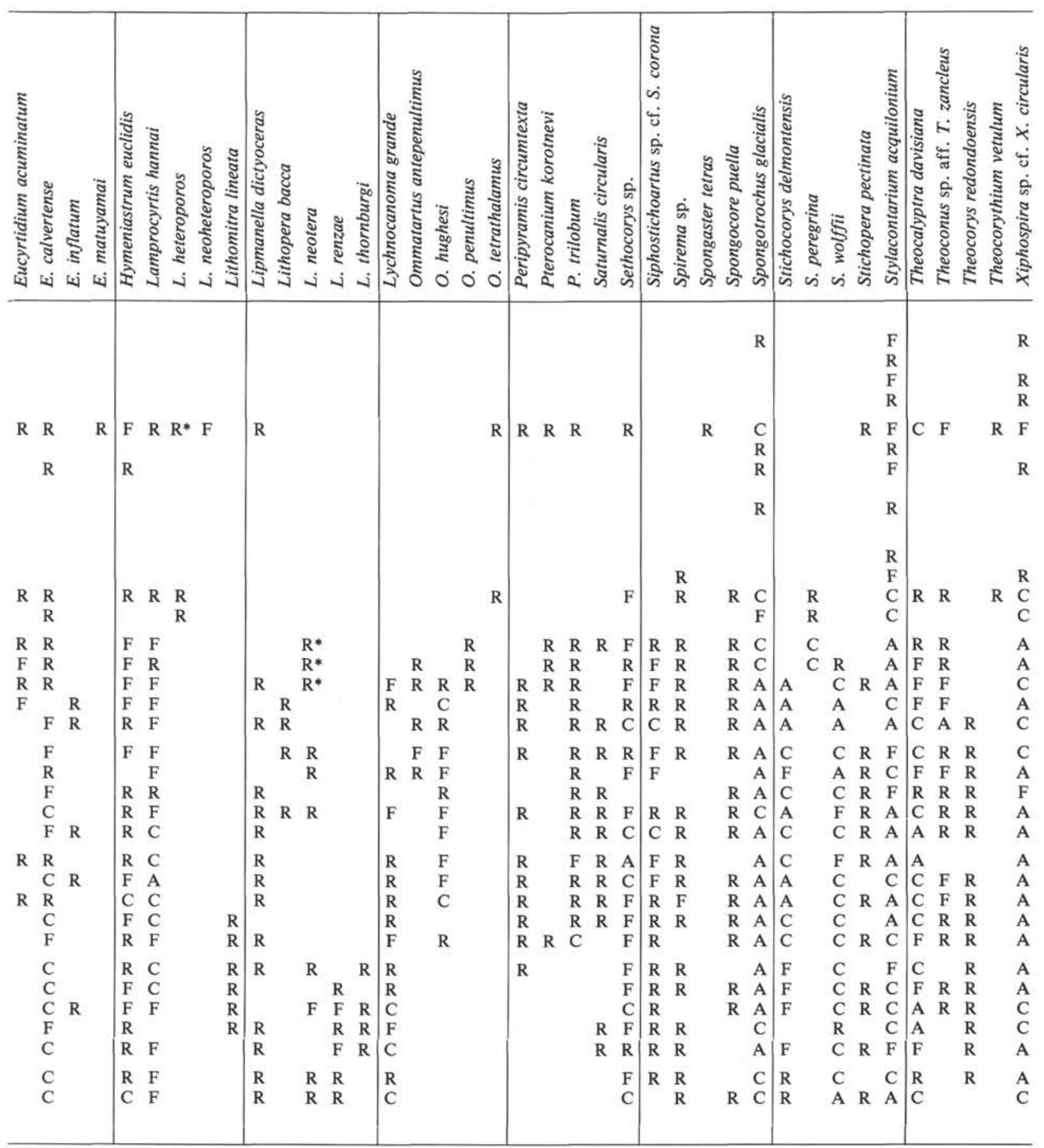

species left to define the upper limit of a possible $O$. penultimus Zone. The lower boundary can be defined rather exactly, however, by the extinction of $O$. hughesi and by the first appearance of $O$. penultimus. The boundary can therefore be placed below Section 17-1, provided that the two events are not simulated by dissolution or reworking. Besides several nondiagnostic species, Sample 17,CC contains $S$. delmontensis, S. wolffii, and $O$. antepenultimus, and Section 23-1 yielded rare to few specimens of $O$. antepenultimus, $O$. hughesi, and
Cannartus petterssoni (O. antepenultimus Zone). Samples $23, \mathrm{CC}$ and $28, \mathrm{CC}$ contain very rare and poorly preserved lower upper Miocene radiolarian assemblages. All of the remaining cores of Site 471 lack radiolarians or bear only indeterminable fragments, frequently with heavy crystalline overgrowths.

\section{Site $\mathbf{4 7 2}$}

Hole 472 was drilled to the west of Site 471 to obtain a pelagic upper Neogene record at this latitude away 
Table 7. Radiolarians from the Neogene and Quaternary sediments of Hole 470A.

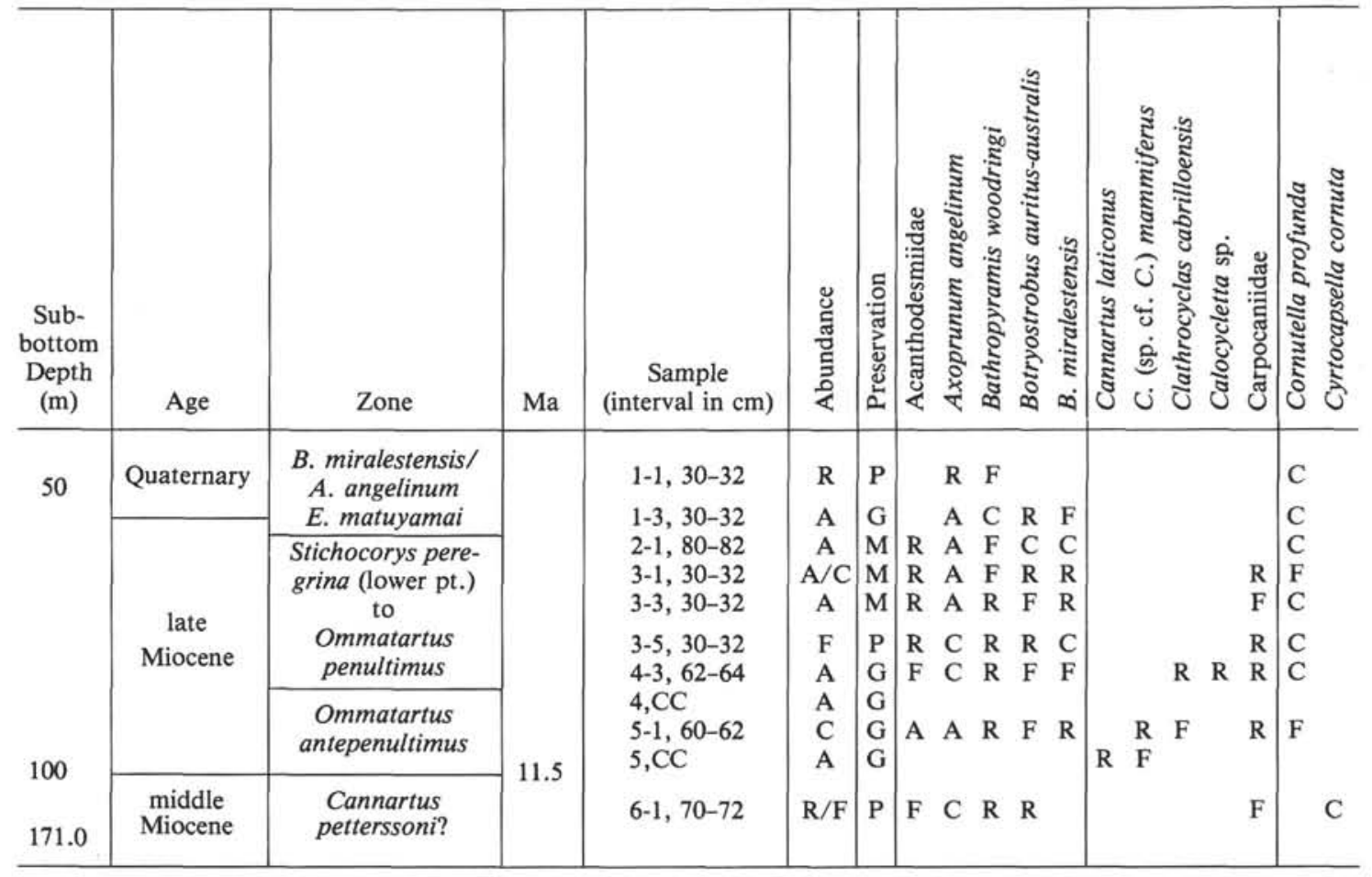

Note: See Table 2 for a key to the symbols.

from terrigenous influences such as those affecting Site 471. Hole 472 was continuously cored to the basaltic base at 112 meters.

The uppermost Sample 472-1-1, 1-2 cm contains a typical equatorial radiolarian assemblage deposited in the early Quaternary (? through late Pliocene), which is composed of Amphirhopalum ypsilon, Ommatartus tetrathalamus, Pterocanium praetextum, P. prismatium, Theocorythium trachelium, $T$. vetulum, etc. The usually more frequent equatorial species Spongaster tetras is lacking.

Rare to common, poorly preserved nondiagnostic radiolarians were recovered from Section 1-1 through Sample 1,CC. Cores 2 through 3 are barren, Cores 5 through 12 contain rare to abundant, poorly to wellpreserved radiolarian assemblages deposited in the early late through middle middle Miocene. Sample 13,CC consists only of downhole contaminants. Radiolarians from the Neogene and Quaternary sediments of Hole 472 are listed in Table 9.

The Miocene radiolarian assemblages are also composed of warm-water species. Section 4-1 yielded few, nondiagnostic radiolarians; Section 5-1 through Section 6-1 contain Ommatartus penultimus, O. antepenultimus, O. hughesi, Stichocorys peregrina, S. delmontensis, and $S$. wolffii and can be assigned, therefore, to the O. penultimus Zone. Riedel and Sanfilippo (1978) placed the boundary between $O$. penultimus and $O$. antepenultimus Zones immediately above the last occurrence of $O$. hughesi. Therefore the $O$. penultimus Zone would only comprise Section 5-1 at Site 472. Alternatively, this boundary can be drawn below the first appearance of $O$. penultimus. Deposition in the early late
Miocene (O. antepenultimus Zone) is indicated by the rare to common presence of $O$. antepenultimus, $O$. hughesi, rare to abundant occurrences of $S$. delmontensis and S. wolffii (Section 6-3 through Section 9-1), and by the absence of $O$. penultimus and $S$. peregrina. The boundary between middle and upper Miocene (i.e., the boundary between $C$. petterssoni and $O$. antepenultimus Zone) may just as well be placed immediately below the first appearances of $O$. hughesi and $O$. antepenultimus (below Section 9-1) as above the last presence of $C$. petterssoni (Section 8-1).

Deposition in the late middle Miocene (C. petterssoni Zone) is suggested for Section 9-3 (or Section 8-3) through Section 10-1 by the presence of $C$. petterssoni and $C$. laticonus, as well as by less diagnostic species such as $S$. delmontensis, $S$. wolffii, and Cyrtocapsella japonica.

The deepest part of the succession at Site 472, below Section $10-1$, possibly belongs to the Dorcadospyris alata Zone, because it contains $C$. laticonus and various species of Cyrtocapsella and lacks $S$. petterssoni.

\section{Site 473}

Hole 473 on the Rivera Plate south of Tres Marias Islands was cored continuously to obtain an upper Neogene reference section at the mouth of the Gulf of California east of the crest of the East Pacific Rise. The hole penetrated 287.1 meters to the basaltic rocks.

Rare to common, poorly to moderately preserved upper Quaternary radiolarians were recovered from Cores 1 through 4 . Cores 5 through 16 are barren or contain only very rare, mainly nondiagnostic radiolarians. Cores 17 through 21 , Section 1 yielded rare to abun- 
Table 7. (Continued).

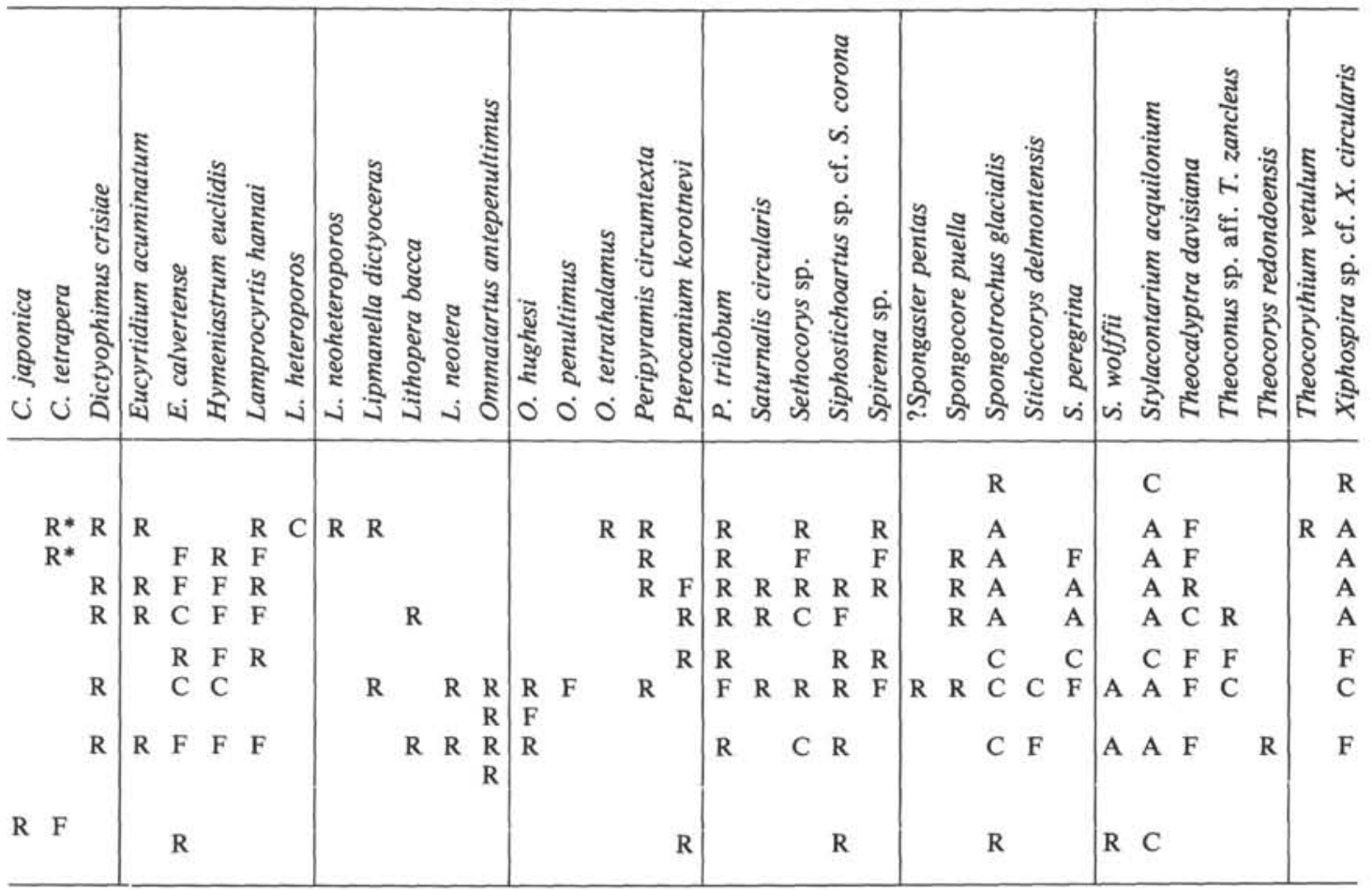

dant, poorly to well-preserved lower Pliocene radiolarian assemblages. The rare and poorly preserved radiolarians from Section 21-3 through Section 23-3 indicate that deposition took place in the late Miocene. Cores 24 through 28 are entirely barren. Table 10 lists radiolarians from the Neogene and Quaternary sediments of Hole 473.

Samples $1, C C$ through $4, C C$ contain a mixed radiolarian assemblage composed of the typical equatorial species Amphirhopalum ypsilon, Anthocyrtidium angulare, Ommatartus tetrathalamus, Pterocanium praetextum, Spongaster tetras, Theocorythium trachelium, and $T$. vetulum and of the Northeast Pacific cold-water species Lamprocyrtis nigriniae, L. neoheteroporos, and L. heteroporos. According to Dinkelman (1973), the presence of $A$. angulare and $T$. vetulum suggests deposition in the early Quaternary, because both species are assumed to be restricted to the basal Quaternary $A$. angulare Zone and because Collosphaera tuberosa and Buccinosphaera invaginata, which make their earliest appearance in late Quaternary sediments, are absent. Nannofossils, diatoms, and $L$. nigriniae indicate, however, that Cores 1 through 4 were deposited in the late Quaternary. Consequently, $A$. angulare and $T$. vetulum could not have become extinct during the early Quaternary but continued until the late Quaternary $(0.45-$ $0.7 \mathrm{Ma}$ ), unless they were reworked. This means that the radiolarian zonation of the equatorial Quaternary cannot be used in the region of Site 473 .

Section 16-5 through Section 21-1 can be assigned to the lower Pliocene (upper part of the Stichocorys peregrina Zone), because this succession yielded rare to abundant individuals of $S$. peregrina, some rare specimens of Spongaster pentas(?), Ommatartus tetrathal- amus, O. penultimus, and Lamprocyrtis heteroporos. The boundary between upper Miocene and lower Pliocene (i.e., between the lower and the upper part of the $S$. peregrina Zone) is placed beneath the first appearance of $L$. heteroporos (Section 21-1). The upper upper Miocene succession is part of the lower $S$. peregrina Zone, because it sporadically contains $S$. peregrina and Ommatartus penultimus (Sections 21-3 through 23-3).

\section{NEOGENE AND QUATERNARY RADIOLARIAN ZONATION}

Figure 3 shows the generalized ranges of selected Neogene and Quaternary species from Sites 467 through 473. They coincide largely with the ranges cited by Kling (1973). Hay's and Kling's zonation for the Pliocene and Quaternary of the East Pacific Coast (California Current) could be recognized in all of the Leg 63 sites. For the Miocene part of the drilled sections, the zonation of the equatorial Pacific (Riedel and Sanfilippo, 1970, 1971) has been used. According to the Leg 63 results, the Quaternary and Neogene zones are defined as follows at Sites 467 to 473 .

\section{Botryostrobus miralestensis Zone Hays, 1970}

This zone could not be recognized. Axoprunum angelinum, which is assumed to become extinct at the base of the zone, extends to the top of the drilled sediments and is associated with $B$. miralestensis.

\section{Axoprunum angelinum Zone Hays, 1970}

The base of this zone is defined by the extinction of Eucyrtidium matuyamai and approximately by the first appearance of Lamprocyrtis nigriniae. 
Table 8. Radiolarians from the Neogene and Quaternary sediments of Hole 471.

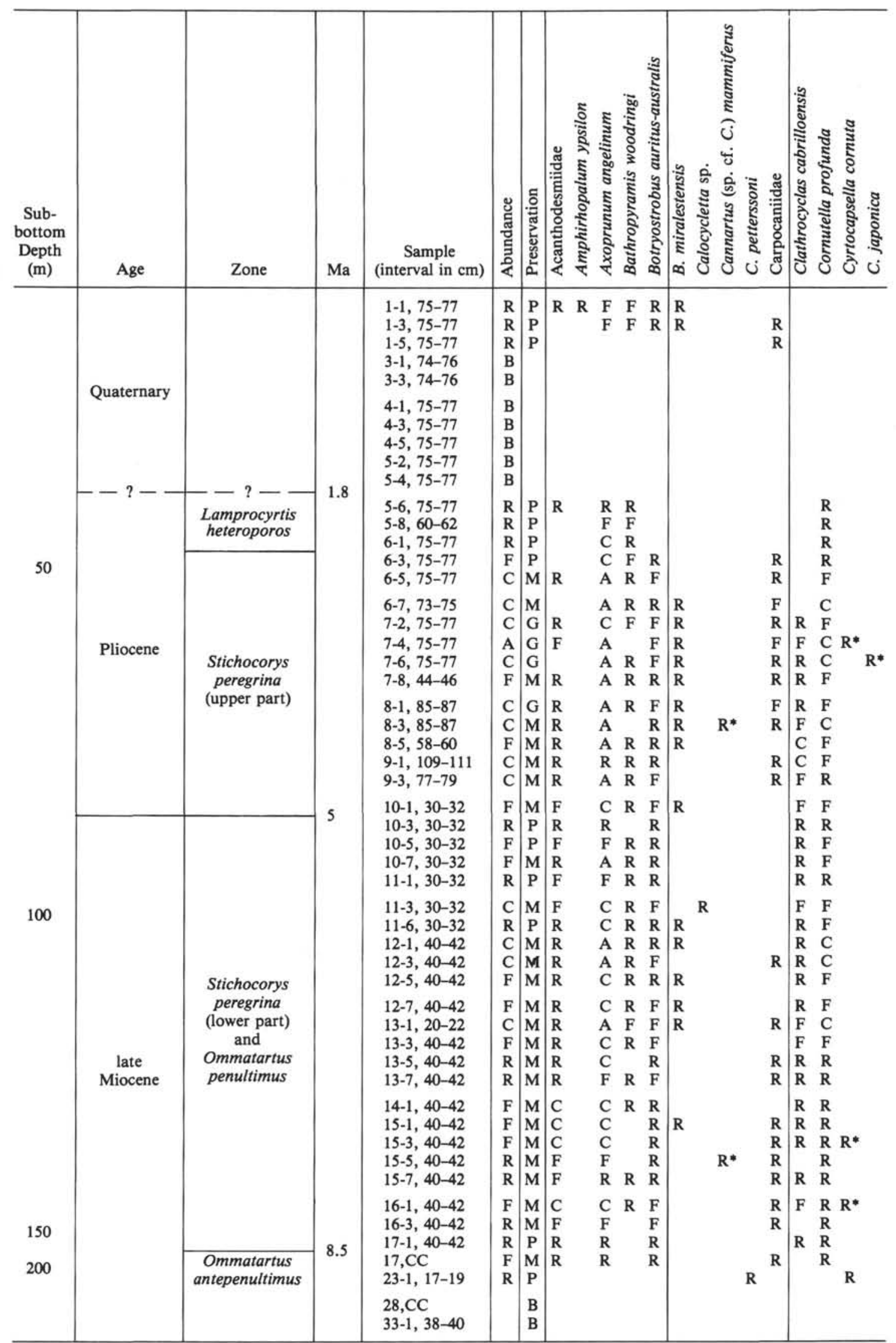

Note: See Table 2 for a key to the symbols. 


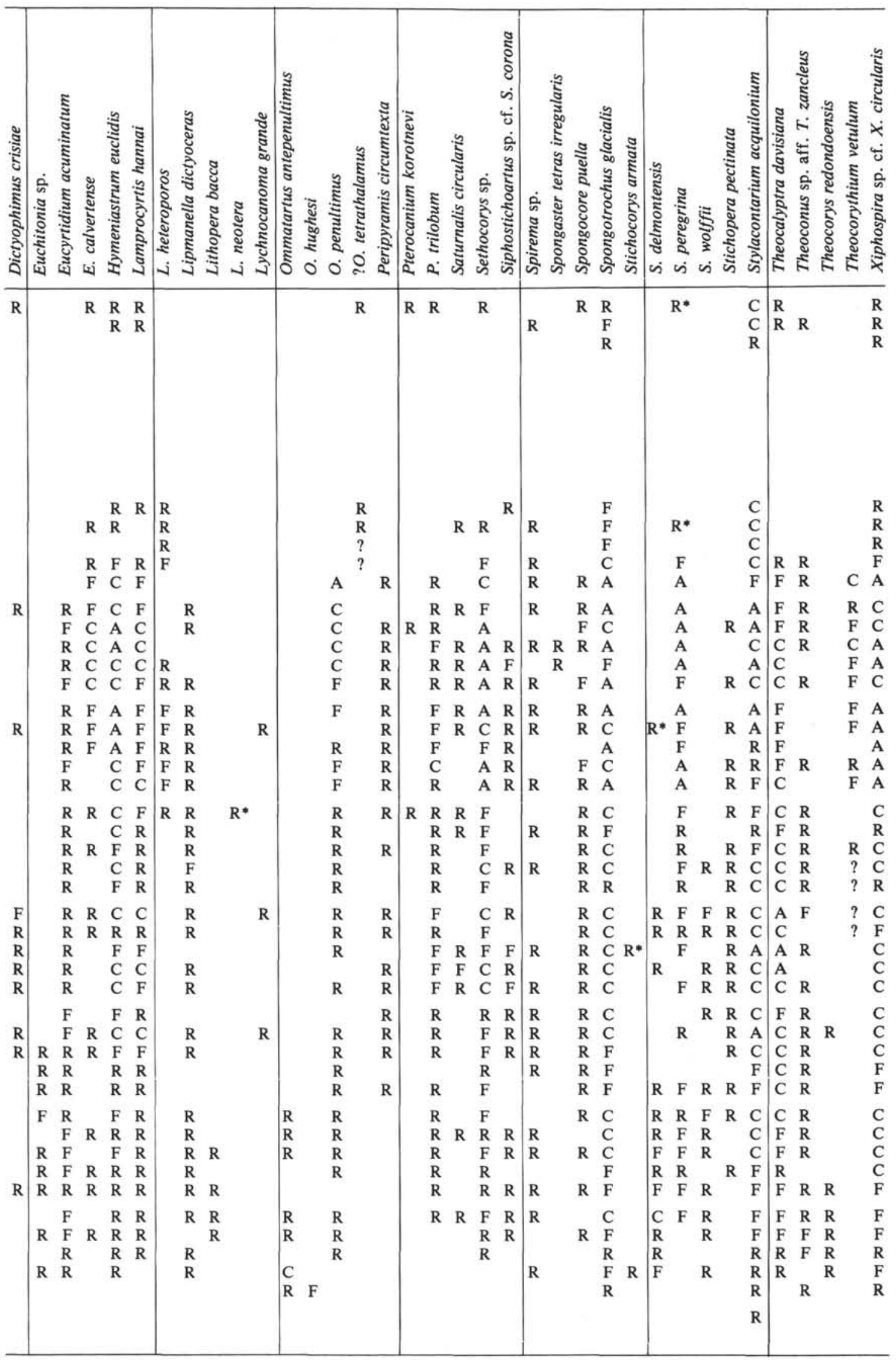


Table 9. Radiolarians from the Neogene and Quaternary sediments of Hole 472.

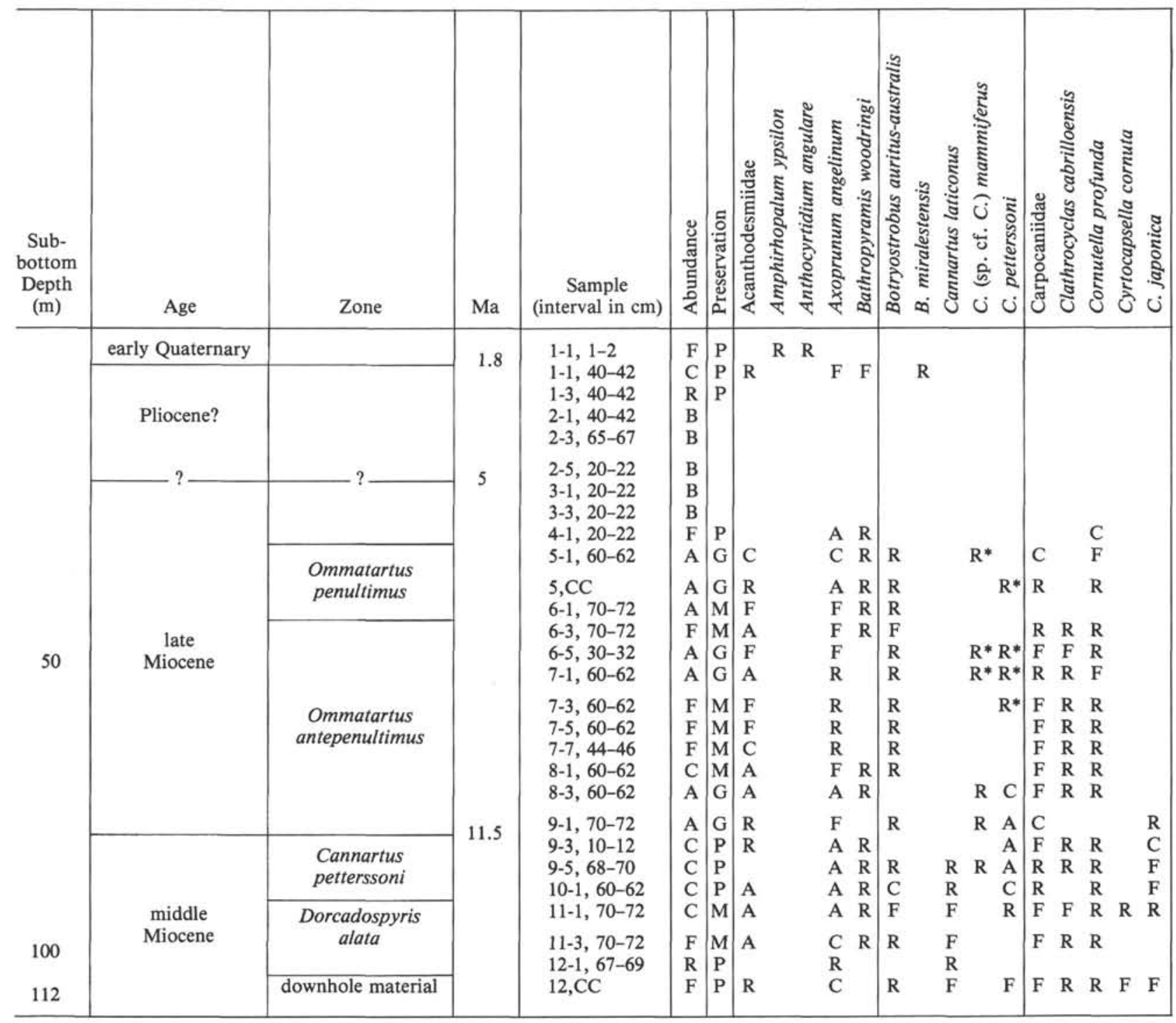

\section{Eucyrtidium matuyamai Zone Hays, 1970}

This zone is defined by the range of E. matuyamai. It includes the last occurrences of Lamprocyrtis heteroporos and the first appearance of Lamprocyrtis neoheteroporos.

\section{Lamprocyrtis heteroporos Zone Hays, 1970}

The base is defined by the occurrence of $L$. heteroporos subsequent to the extinction of Stichocorys peregrina and Ommatartus penultimus and the top by the first appearance of Eucyrtidium matuyamai.

\section{Stichocorys peregrina Zone Riedel and Sanfilippo, 1970}

The top of the zone is approximately indicated by the last occurrence of $S$. peregrina and by the first occurrences of Amphirhopalum ypsilon and A. wirchowii. The zone includes the boundary between Miocene and Pliocene, which is tentatively identified as the earliest appearance of Lamprocyrtis heteroporos (Kling, 1973). Consequently, the $S$. peregrina Zone can be divided into an upper part with, and a lower part without, $L$. heteroporos. There are also several species (such as Anthocyrtidium angulare, Ommatartus tetrathalamus, Pterocanium praetextum, Spongaster tetras, and Theocorythium vetulum) that have their first occurrences as well as several species (such as Theocorys redondoensis, Stichocorys delmontensis, and Ommatartus antepenultimus) that have their last occurrences in the lower part of the S. peregrina Zone in the Leg 63 area.

The base of the Stichocorys peregrina Zone is difficult to recognize. It is approximately indicated by decreasing abundances of $T$. redondoensis, $S$. delmontensis, and $O$. antepenultimus. There is apparently a considerable overlap in morphotypic ranges of Stichocorys delmontensis and S. peregrina (Kling 1973), the latter of which first appears in the $O$. antepenultimus Zone.

\section{Ommatartus penultimus Zone Riedel and Sanfilippo, 1970}

The base of the zone is defined by the first appearance of $O$. penultimus, the top, by the base of the $S$. 
Table 9. (Continued).

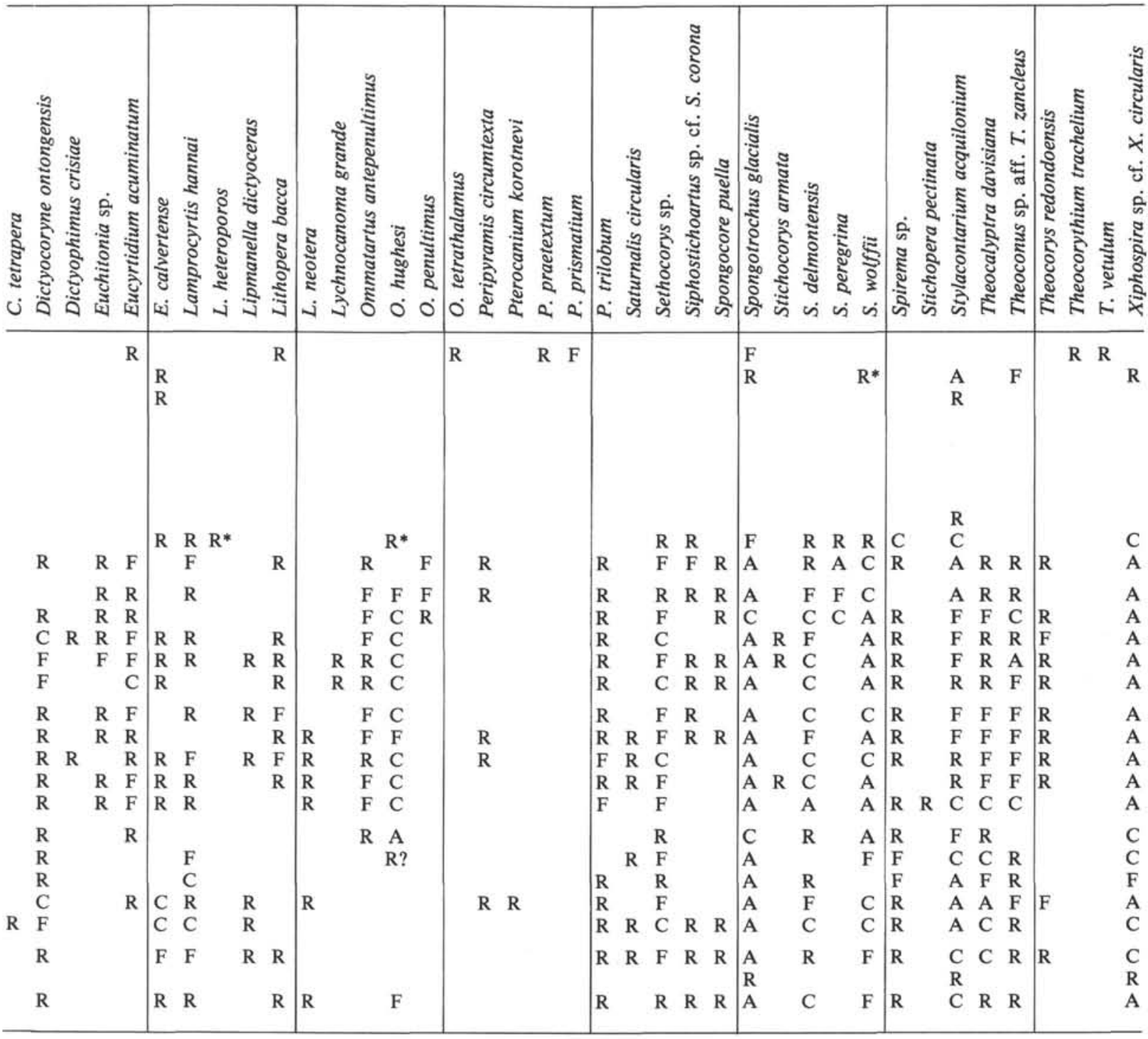

peregrina Zone. The zone includes the final extinction of Lithopera neotera, Ommatartus hughesi, and Stichocorys wolffii within the Leg 63 region.

\section{Ommatartus antepenultimus Zone \\ Riedel and Sanfilippo, 1970}

The base is defined by the first appearance of $O$. antepenultimus, the top by the base of the $O$. penultimus Zone. Numerous species have their last appearance within this zone: Cannartus laticonus, C. mammiferus, C. petterssoni, Cyrtocapsella cornuta, C. japonica, C. tetrapera, Eucyrtidium inflatum, and Lithopera renzae.

Cannartus petterssoni Zone Riedel and Sanfilippo, 1970

The base of the zone is defined by the first appearance of $C$. petterssoni, the top by the base of the $O$. antepenultimus Zone. It is also approximately indicated by the earliest occurrence of Eucyrtidium acuminatum. The zone includes the first occurrence of Ommatartus hughesi.

\section{Dorcadospyris alata Zone Riedel and Sanfilippo, 1970, 1971}

The bottom of the zone was not encountered in the Leg 63 area; the top is defined by the base of the C. petterssoni Zone. In the Leg 63 area, several species make their first appearance within the $D$. alata Zone, such as Cannartus laticonus, C. mammiferus, Eucyrtidium inflatum, Lithopera bacca, L. thornburgii, and Theocorys redondoensis. Some lower Miocene species (Calocycletta costata, $C$. virginis, and Cannartus violina) are still present in the lower part of the $D$. alata Zone, if they are not reworked. 
Table 10. Radiolarians from the Neogene and Quaternary sediments of Hole 473.

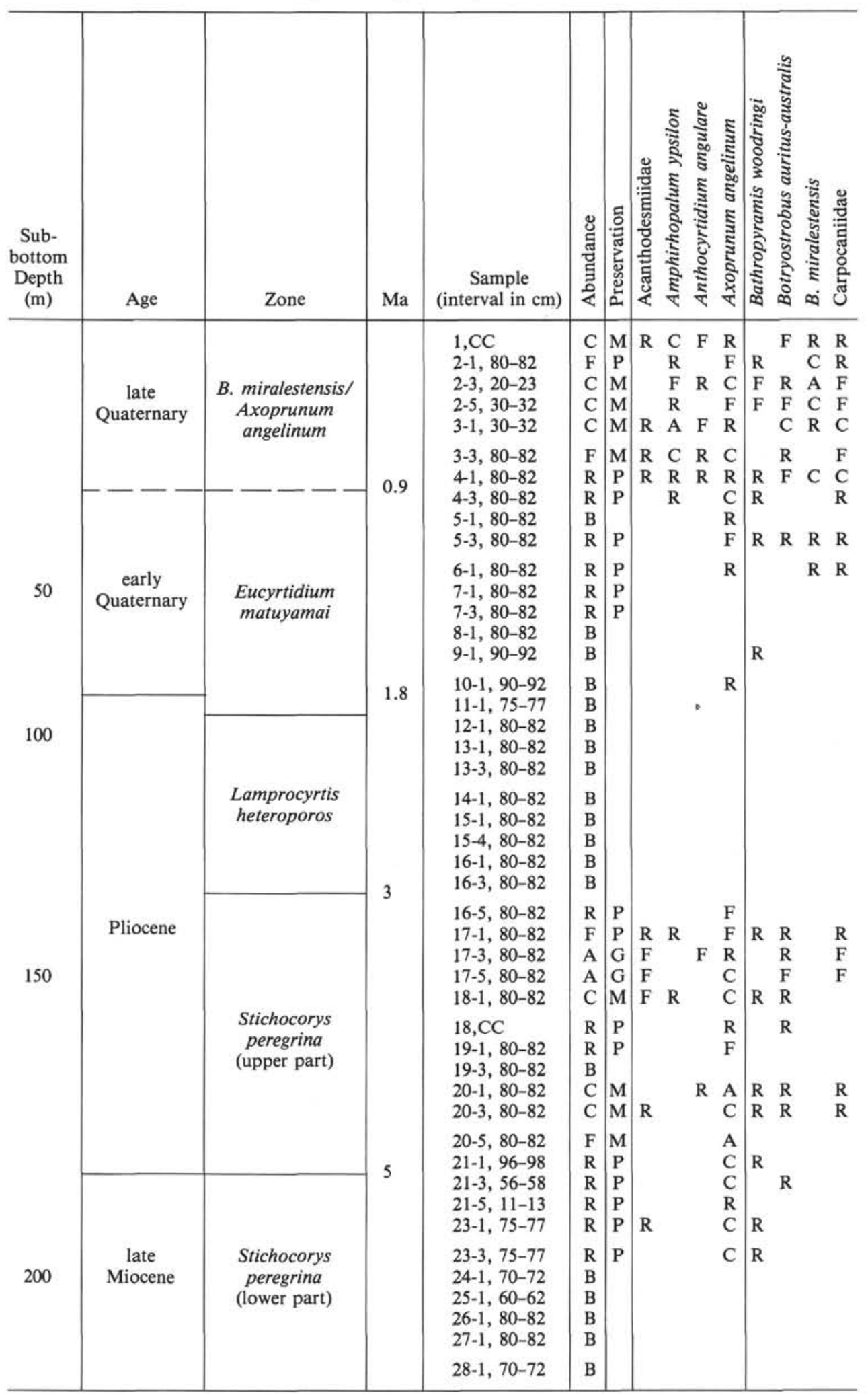

Note: See Table 2 for a key to the symbols. 
Table 10. (Continued).

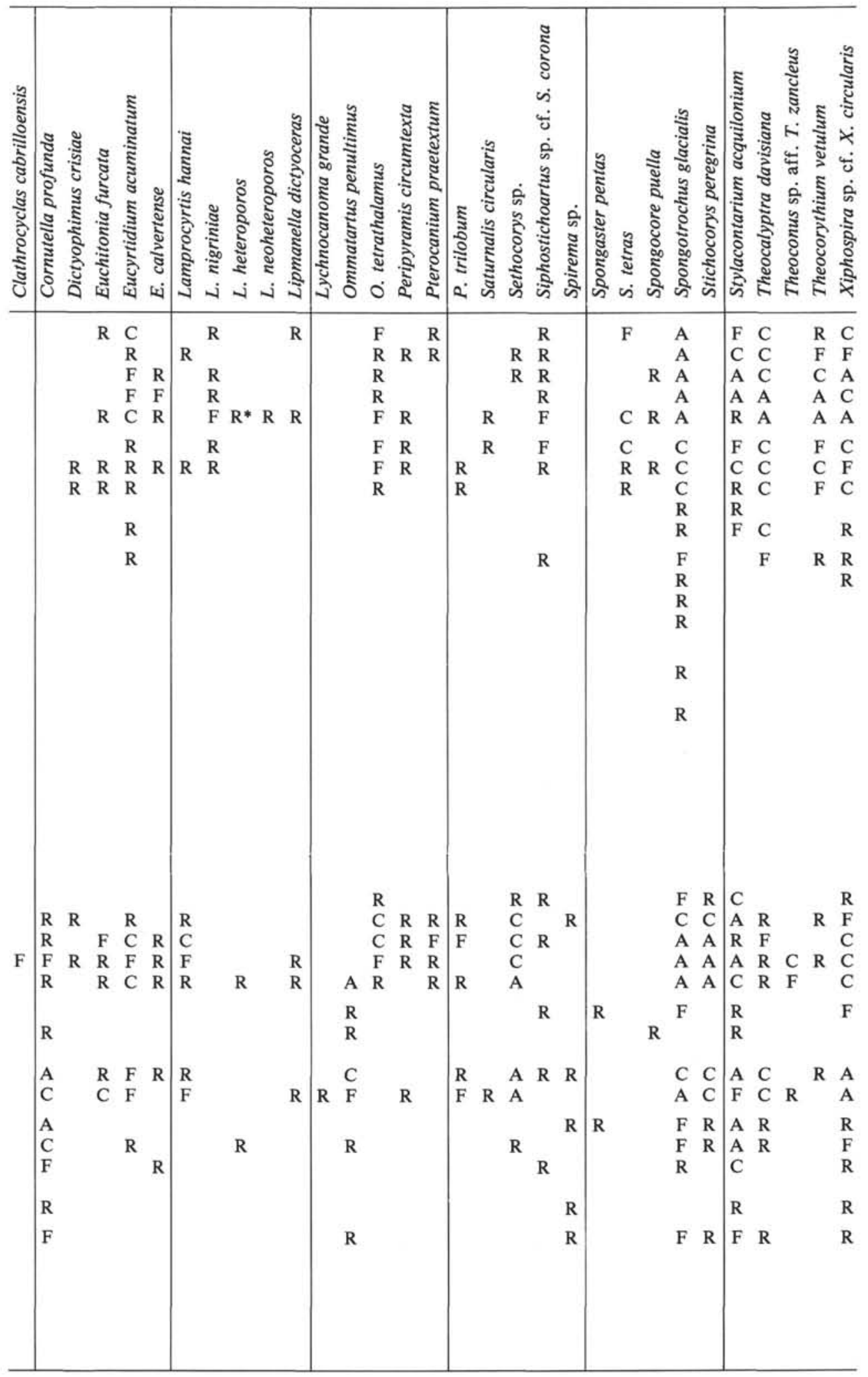




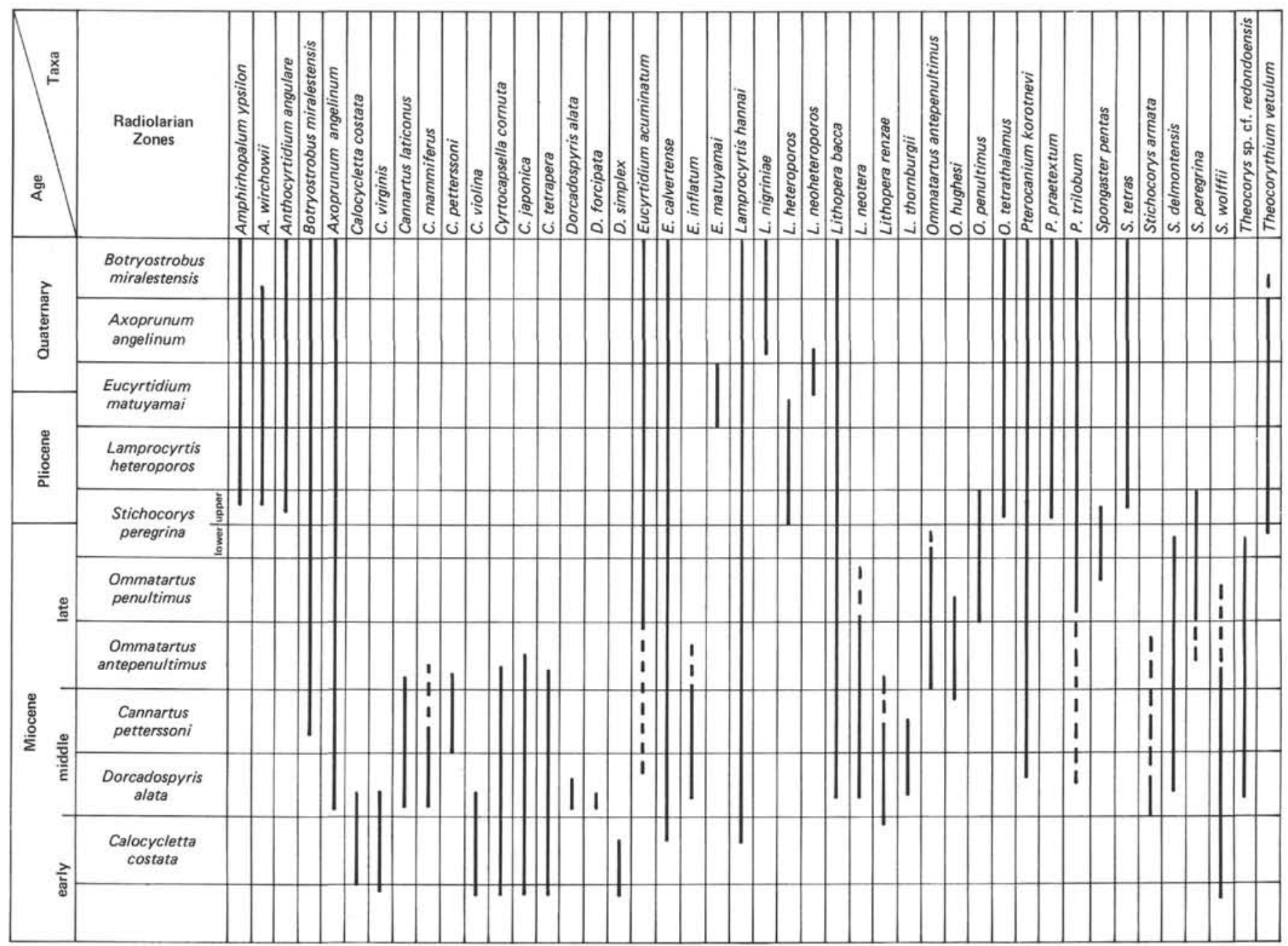

Figure 3. Generalized range chart for Neogene and Quaternary radiolarians from Sites 467 to 473.

\section{TAXONOMY}

ACANTHODESMIIDAE Haeckel, 1862, emend. Riedel, $1967 \mathrm{~b}$.

Acanthodesmiidae, gen. et spp. indet., Kling, 1973, p. 635, pl. 2, figs. 8-14; pl. 8, figs. 1-26.

\section{Amphirhopalum wirchowii (Haeckel)}

(Plate 3, Figs. 1-3)

Euchitonia wirchowii Haeckel, 1862, p. 503, pl. 30, figs. 1-4.

Amphirhopalum wirchowii (Haeckel), Dumitricá, 1973, p. 835, pl. 9 , figs. 2 and 4 ; pl. 11, fig. 6; pl. 21, figs. 2-13.

\section{Amphirhopalum ypsilon Haeckel}

Amphirhopalum ypsilon Haeckel, 1867, p. 522; Nigrini, 1967, p. 35 , pl. 3, figs. 3a-d; 1970, pl. 2, fig. 2; Dinkelman, 1973, p. 768, pl. 10, fig. 10 .

\section{Anthocyrtidium sp. cf. A. angulare Nigrini}

Anthocyrtidium angulare Nigrini, 1971 , p. 445 , pl. 34.1 , figs. $3 a$, b; Dinkelman, 1973, p. 788, pl. 10, fig. 5.

\section{Axoprunum angelinum (Campbell and Clark)}

Stylosphaera angelina Campbell and Clark, 1944, p. 12, pl. 1, figs. 14-20.

Axoprunum angelinum (Campbell and Clark), Kling, 1973, p. 634, pl. 1 , figs. 13-16, pl. 6, figs. 14-18.

\section{Bathropyramis woodringi Campbell and Clark (Plate 4, Fig. 2)}

Bathropyramis woodringi Campbell and Clark, 1944, p. 39, pl. 5, figs. 21, 22.

Bathropyramis woodringi Campbell and Clark, Kling, 1973, pl. 2, figs. 20-23; pl. 9, figs. 5, 7 .

\section{Botryostrobus auritus-australis (Ehrenberg) group}

Lithocampe aurita Ehrenberg, 1844, p. 84; 1854, pl. 22, fig. 25.

Artostrobium auritum (Ehrenberg) group, Riedel and Sanfilippo, 1971 , p. 1599 , pl. $1 \mathrm{H}$, figs. 5-8.

Artostrobium auritum (Ehrenberg), Kling, 1973, p. 639, pl. 5, figs. 27-30; pl. 12, figs. 24-27.

Botryostrobus auritus-australis (Ehrenberg) group, Nigrini, 1977, p. 246 , pl. 1 , figs. $2-5$.

\section{Botryostrobus miralestensis (Campbell and Clark)} (Plate 2, Figs. 8-10)

Dictyocephalus miralestensis Campbell and Clark, 1944, p. 45, pl. 6, figs. 12-14.

Artostrobium miralestense (Campbell and Clark), Riedel and Sanfilippo, 1971, p. 1599, pl. 1H, figs. 9-17; pl. 2J, figs. 9, 10; pl. 3E, fig. 12.

Artostrobium miralestense (Campbell and Clark), Kling, 1973, p. 639, pl. 5, figs. 31-35; pl. 12, figs. 28-31.

Botryostrobus miralestensis (Campbell and Clark), Nigrini, 1977, p. 449 , pl. 1, fig. 9. 


\section{Calocycletta costata (Riedel)}

(Plate 4, Fig. 6)

Calocyclas costata Riedel, 1959, p. 296, pl. 2, fig. 9.

Calocycletta costata (Riedel), Riedel and Sanfilippo, 1971, p. 1598, pl. $2 \mathrm{H}$, figs. $12-14$.

\section{Calocycletta virginis (Haeckel)}

Calocyclas (Calocycletta) virginis Haeckel, 1887, pl. 74, fig. 4. Calocycletta virginis (Haeckel), Riedel and Sanfilippo, 1971, pl. 2H, figs. 5-11.

\section{Cannartus laticonus Riedel} (Plate 5, Figs. 6-7)

Cannartus laticonus Riedel, 1959, pl. 291, pl. 1, fig. 5.

Cannartus laticonus Riedel, Riedel and Sanfilippo, 1971, p. 1587, pl. 1C, figs. 13, 14.

Cannartus laticonus Riedel, Moore, 1971, p. 736, pl. 12, fig. 6.

Cannartus laticonus Riedel, Kling, 1973, p. 634, pl. 7, fig. 7.

\section{Cannartus sp. cf. C. mammiferus (Haeckel)} (Plate 5, Figs. 11-12)

Cannartidium mammiferum Haeckel, 1887, p. 375, pl. 39, fig. 16. Cannartus mammiferum (Haeckel), Riedel, 1959, p. 291, pl. 1, fig. 4. Cannartus mammiferum (Haeckel), Moore, 1971, p. 736, pl. 12, fig. 5 .

Cannartus mammiferus (Haeckel), Riedel and Sanfilippo, 1971, p. 1587 , pl. 2C, figs. $1-3$.

\section{Cannartus petterssoni Riedel and Sanfilippo}

(Plate 5, Figures 11-12)

Cannartus? petterssoni Riedel and Sanfilippo, 1970, p. 520, pl. 14, fig. 3 .

Cannartus? petterssoni Riedel and Sanfilippo, 1971, p. 1587, pl. 1C, figs. 19-20.

Cannartus? petterssoni Riedel and Sanfilippo, Moore, 1971, p. 737, pl. 12, fig. 7.

Cannartus? petterssoni Riedel and Sanfilippo, Kling, 1973, p. 634, pl. 7 , fig. 8 .

Cannartus? petterssoni Riedel and Sanfilippo, Dinkelman, 1973, p. 766, pl. 8, figs. 5, 9-11.

\section{Cannartus violina Haeckel}

Cannartus violina Haeckel, 1887, p. 538, pl. 39, fig. 10.

Cannartus violina Haeckel, Riedel, 1959, p. 290, pl. 1, fig. 3.

Cannartus violina Haeckel, Moore, 1971, p. 736, pl. 12, fig. 4.

Cannurtus violina Haeckel, Riedel and Sanfilippo, 1971, p. 1588, pl. $2 \mathrm{C}$, figs. 4-7.

Cannartus? sp.

(Plate 4, Fig. 9)

Ommatartus sp. B, Foreman, 1975, p. 618, pl. 8, figs. 24-25.

CARPOCANIIDAE Haeckel 1881, emend. Riedel 1967b. Members of this family are illustrated but not further identified.

Clathrocyclas cabrilloensis Campbell and Clark

Clathrocyclas cabrilloensis Campbell and Clark, 1944, p. 48, pl. 7, figs. 1-3.

Clathrocyclas cabrilloensis Campbell and Clark, Kling, 1973, p. 635, pl. 9, figs. 23-25.

\section{Clathrocyclas sp.}

Clathrocyclas spp., Kling, 1973, p. 635, pl. 3, figs. 17-22; pl. 9, figs. 26-31.

\section{Cornutella profunda Ehrenberg}

Cornutella clathrata profunda Ehrenberg, 1854, pl. 35B, fig. 21.

Cornutella profunda Ehrenberg, Nigrini, 1967, p. 60, pl. 6, figs. 5a-c.
Cornutella profunda Ehrenberg, Kling, 1973, p. 635, pl. 3, figs. 1-4; pl. 9, figs. 8-17.

Cornutella profunda Ehrenberg, Riedel and Sanfilippo, 1978, p. 114, pl. 4 , fig. 8 .

\section{Cyrtocapsella cornuta Haeckel}

Cyrtocapsa (Cyrtocapsella) cornuta Haeckel, 1887, p. 1513, pl. 78, fig. 9.

Cyrtocapsella cornuta Haeckel, Riedel and Sanfilippo, 1971, p. 1593, pl. 2E, figs. 1-4.

Cyrtocapsella cornuta Haeckel, Kling, 1973, p. 636, pl. 11, figs. 16-18.

\section{Cyrtocapsella japonica (Nakaseko)}

(Plate 3, Figs. 5-6)

Eusyringium japonicum Nakaseko, 1963, p. 193, pl. 4, figs. 1-3.

Cyrtocapsella japonica (Nakaseko), Sanfilippo and Riedel, 1970, p. 452 , pl. 1 , figs. $13-15$.

\section{Cyrtocapsella tetrapera Haeckel}

$$
\text { (Plate 3, Fig. 4) }
$$

Cyrtocapsa (Cyrtocapsella) tetrapera Haeckel, 1887, p. 1512, pl. 78, fig. 5.

Cyrtocapsella tetrapera Haeckel, Riedel and Sanfilippo, 1971, p. 1594, , pl. 2 E, figs. 5-7.

Cyrtocapsella tetrapera Haeckel, Kling, 1973, p. 636, pl. 11, figs. 12-15.

\section{Dictyocoryne ontongensis Riedel and Sanfilippo}

Dictyocoryne ontongensis Riedel and Sanfilippo, 1971, p. 1588, pl. $1 \mathrm{E}$, figs. 1, 2; pl. 4, figs. 9-11.

\section{Dictyophimus crisiae Ehrenberg}

Dictyophimus crisiae Ehrenberg, 1854, p. 241.

Dictyophimus crisiae Ehrenberg, Nigrini, 1967, p. 66, pl. 6, figs. $7 \mathrm{a}, 7 \mathrm{~b}$.

Dictyophimus crisiae Ehrenberg, Kling, 1973, p. 636, pl. 4, figs. 1115 ; pl. 10, figs. 18-20.

\section{Dorcadospyris alata (Riedel)}

Brachiospyris alata Riedel, 1959, p. 293, pl. 1, figs. 11, 12.

Dorcadospyris alata (Riedel), Riedel and Sanfilippo, 1971, p. 1590, pl. 2D, fig. 1.

Dorcadospyris alata (Riedel), Moore, 1971, p. 740, pl. 11, figs. 3, 4.

Dorcadospyris forcipata (Haeckel)

Dipospyris forcipata Haeckel, 1887, p. 1037, pl. 85, fig. 1.

Dorcadospyris forcipata (Haeckel), Riedel and Sanfilippo, 1971, p. 1590 , pl. 2C, figs. $20-23$; pl. 3A, fig. 8 .

Dorcadospyris forcipata (Haeckel), Moore, 1971, p. 740, pl. 10, figs. $1,2$.

\section{Dorcadospyris simplex (Riedel)}

Brachiospyris simplex Riedel, 1959, p. 293, pl. 1, fig. 10. Dorcadospyris simplex (Riedel) Moore, 1971, p. 740, pl. 10, figs. 3, 4 .

\section{Euchitonia sp. aff. E. furcata Ehrenberg}

Euchitonia furcata Ehrenberg, 1860, p. 823.

Euchitonia furcata Ehrenberg, Ling and Anicouchine, 1967, p. 1484, pl. 189, figs. 5-7; pl. 190, figs. 5-7.

Euchitonia furcata Ehrenberg, Nigrini, 1970, p. 169, pl. 2, fig. 5.

\section{Eucyrtidium acuminatum (Ehrenberg)}

(Plate 3, Fig. 7)

Lithocampe acuminatum Ehrenberg, 1844, p. 84.

Eucyrtidium acuminatum (Ehrenberg), 1847, p. 43

Eucyrtidium acuminatum (Ehrenberg), Nigrini, 1967, p. 83, pl. 8, figs. $4 \mathrm{a}$, $\mathrm{b}$. 


\section{R. WOLFART}

Eucyrtidium acuminatum (Ehrenberg), Kling, 1973, p. 636, pl. 4, figs. 20-23.

\section{Eucyrtidium calvertense Martin}

(Plate 2, Figs. 12-14)

Eucyrtidium calvertense Martin, 1904, p. 450, pl. 130, fig. 5.

Eucyrtidium calvertense Martin, Kling, 1973, p. 636, pl. 4, figs. 16, 18 , 19; pl. 11, figs. 1-5.

\section{Eucyrtidium inflatum Kling}

(Plate 2, Fig. 15)

Eucyrtidium inflatum Kling, 1973, p. 636, pl. 11, fig. 7; pl. 15, figs. 7-10.

\section{Eucyrtidium matuyamai Hays}

(Plate 3, Figs. 8-9, 10?)

Eucyrtidium matuyamai Hays, 1970, p. 213, pl. 1, figs. 7-9.

Eucyrtidium matuyamai Hays, Kling, 1973, p. 636, pl. 4, fig. 17.

\section{Hymeniastrum euclidis Haeckel}

Hymeniastrum euclidis Haeckel, 1887, p. 531, fig. 13.

Hymeniastrum euclidis Haeckel, Ling and Anicouchine, 1967, p. 1488 , pls. $191 / 192$, fig. 3 .

Hymeniastrum euclidis Haeckel, Nigrini, 1970, p. 168, pl. 2, fig. 4.

\section{Lamprocyclas maritalis maritalis Haeckel}

(Plate 2, Fig. 11)

Lamprocyclas maritalis Haeckel, 1887.

Lamprocyclas maritalis maritalis Haeckel, Nigrini, 1970, p. 171, pl. 4, fig. 8.

\section{Lamprocyclas maritalis polypora Nigrini}

Lamprocyclas maritalis polypora Nigrini, 1967, p. 76 , pl. 7, fig. 6 . Lamprocyclas maritalis polypora Nigrini, 1970, p. 171, pl. 4, fig. 9 Lamprocyclas maritalis polypora Nigrini, Kling, 1973, pl. 5, fig. 7.

\section{Lamprocyrtis hannai (Campbell and Clark)}

$$
\text { (Plate 1, Fig. 4) }
$$

Calocyclas hannai Campbell and Clark, 1944, p. 48, pl. 69, figs. $21,22$.

Lamprocyrtis? hannai (Campbell and Clark), Kling, 1973, p. 638, pl. 5, figs. $12-14$; pl. 12 , figs. $10-14$.

\section{Lamprocyrtis nigriniae (Caulet)}

(Plate 2, Figs. 1-2)

Conarachnium nigriniae Caulet, 1971, p. 3, pl. 3, figs. 1-4; pl. 4, figs. 1-4.

Lamprocyrtis haysi Kling, 1973, p. 639, pl. 5, figs. 15, 16; pl. 15, figs. 1-3.

Lamprocyrtis nigriniae (Caulet), Kling, 1979, p. 309, pl. 2, fig. 26.

\section{Lamprocyrtis heteroporos (Hays)}

(Plate 2, Figs. 4, 6, 7)

Lamprocyclas heteroporos Hays, 1965, p. 179, pl. 3, fig. 1 .

Lamprocyrtis heteroporos (Hays), Kling, 1973, p. 639, pl. 5, figs. 1921 ; pl. 15, fig. 6 .

\section{Lamprocyrtis neoheteroporos Kling}

(Plate 2, Figs. 3 and ?5)

Lamprocyrtis neoheteroporos Kling, 1973, p. 639, pl. 5, figs. 17, 18; pl. 15 , figs. 4,5 .

\section{Lipmanella dictyoceras (Haeckel)}

Lithornithium dictyoceras Haeckel, 1860, p. 840.

Lipmanella wirchowii (Haeckel), Petrushevskaya, 1971, p. 220, fig. 198.

Lipmanella dictyoceras (Haeckel), Kling, 1973, p. 636, pl. 4, figs. 24-26.

\section{Lithomitra lineata (Ehrenberg) group}

Lithocampe lineata Ehrenberg, 1838, p. 130 (partim); 1858, pl. 22, fig. 26; pl. 36, fig. 16 .

Lithomitra lineata (Ehrenberg) group, Riedel and Sanfilippo, 1971, p. 1600 , pl. 1J, figs. 1-11; pl. 2J, figs. 14-16; pl. 3E, fig. 14.

Lithomitra lineata (Ehrenberg), Kling, 1973, p. 639, pl. 12, figs. $19,20$.

\section{Lithopera bacca Ehrenberg}

Lithopera bacca Ehrenberg, 1872a, p. 314; 1872b, pl. 8, fig. 1.

Lithopera bacca Ehrenberg, Riedel and Sanfilippo, 1971, p. 1594, pl. $1 \mathrm{~F}$, figs. 10-13.

Lithopera bacca Ehrenberg, Kling, 1973, p. 636, pl. 11, figs. 21, 22.

\section{Lithopera neotera Sanfilippo and Riedel}

Lithopera neotera Sanfilippo and Riedel, 1970, p. 454, pl. 1, figs. 2426, 28.

Lithopera neotera Sanfilippo and Riedel, Kling, 1973, p. 636, pl. 11, fig. 23.

\section{Lithopera renzae Sanfilippo and Riedel}

(Plate 1, Fig. 13)

Lithopera renzae Sanfilippo and Riedel, 1970, p. 454, pl. 1, figs. 21$23,27$.

Lithopera renzae Sanfilippo and Riedel, Kling, 1973, p. 636, pl. 11, fig. 25 .

\section{Lithopera thornburgi Sanfilippo and Riedel}

Lithopera thornburgi Sanfilippo and Riedel, 1970, p. 455, pl. 2, figs. 4-6.

Lithopera thornburgi Sanfilippo and Riedel, Kling, 1973, p. 636, pl. 11 , fig. 24.

\section{Lychnocanoma grande (Campbell and Clark)}

Lychnocanium grande Campbell and Clark, 1944, p. 42, pl. 6, figs. 3-6.

Lychnocanoma grande (Campbell and Clark), Kling 1973, p. 637, pl. 10 , figs. $10-14$

Ommatartus antepenultimus Riedel and Sanfilippo (Plate 5, Figs. 3-5)

Ommatartus antepenultimus Riedel and Sanfilippo, 1970, p. 521, pl. 14, fig. 4.

Ommatartus antepenultimus Riedel and Sanfilippo, Moore, 1971, p. 737 , pl. 12 , figs. $9,10$.

Ommatartus antepenultimus Riedel and Sanfilippo, 1971, p. 1588, pl. $1 \mathrm{C}$, figs. 11,12 .

\section{Ommatartus hughesi (Campbell and Clark)} (Plate 5, Fig. 8)

Ommatocampe hughesi Campbell and Clark, 1944, p. 23, pl. 3, fig. 12 .

Ommatartus hughesi (Campbell and Clark), Riedel and Sanfilippo, 1970 , p. $521 ; 1971$, p. 1588 , pl. 1C, figs. $17,18$.

Ommatartus hughesi (Campbell and Clark), Moore, 1971, p. 737, pl. 12, fig. 8 .

\section{Ommatartus penultimus (Riedel)}

(Plate 5, Figs. 1-2)

Panarium penultimum Riedel, 1957 , p. 76 , pl. 1, fig. 1.

Ommatartus penultimus (Riedel), Riedel and Sanfilippo, 1971, p. 1588 , pl. 1C, figs. 8-10.

Ommatartus penultimus (Riedel), Moore, 1971, p. 737, pl. 12, fig. 11.

\section{Ommatartus tetrathalamus (Haeckel)} (Plate 4, Fig. 7)

Panartus tetrathalamus Haeckel, 1887, p. 378 , pl. 40, fig. 3. Ommatartus tetrathalamus (Haeckel), Moore, 1971, p. 737, pl. 12, fig. 12 . 
Ommatartus tetrathalamus (Haeckel), Riedel and Sanfilippo, 1971, p. 1588, pl. 1C, figs. 5-7.

\section{Ommatartus sp. cf. Cannartus bassanii (Carnevale)}

(Plate 4, Fig. 4)

Ommatartus sp. cf. Cannartus bassanii (Carnevale), cf. Foreman, 1975 , p. 619 , pl. 8, figs. 11-12.

\section{Peripyramis circumtexta Haeckel}

(Plate 3, Fig. 11)

Peripyramis circumtexta Haeckel, 1887, p. 1162, pl. 54, fig. 5 .

Peripyramis circumtexta Haeckel, Kling, 1973, p. 637, pl. 2, figs. 15, 16; pl. 9, figs. 1-3.

\section{Phormostichoartus doliolum (Riedel and Sanfilippo)}

Artostrobium doliolum Riedel and Sanfilippo, 1971, p. 1599, pl. 1H, figs. $1-3$; pl. 8 , figs. 14,15 .

Phormostichoartus doliolum (Riedel and Sanfilippo), Nigrini, 1977, p. 252 , pl. 1, fig. 14

\section{Pterocanium korotnevi (Dogiel and Reshetnyak) (Plate 4, Fig. 3)}

Pterocorys korotnevi Dogiel and Reshetnyak, 1952, p. 17, fig. 11. Pterocanium korotnevi (Dogiel and Reshetnyak), Nigrini, 1970, p. 170 , pl. 3 , figs. 10,11 .

Pterocanium korotnevi (Dogiel and Reshetnyak), Kling, 1973, p. 638, pl. 4 , figs. 1-4.

\section{Pterocanium praetextum (Ehrenberg)}

Lychocanium praetextum (Ehrenberg), 1872a, p. 316.

Pterocanium praetextum (Ehrenberg), Haeckel, 1887, p. 1330.

Pterocanium praetextum (Ehrenberg), Nigrini, 1970, pl. 3, fig. 7.

Pterocanium praetextum (Ehrenberg), Moore, 1971, pl. 13, fig. 3.

\section{Pterocanium prismatium Riedel}

Pterocanium prismatium Riedel, 1957, p. 87, pl. 3, figs. 4-5.

Pterocanium prismatium Riedel, Riedel and Sanfilippo, 1971, p. 1595 , pl. 8, fig. 1.

Pterocanium prismatium Riedel, Moore, 1971, pl. 13, figs. 1, 2.

Pterocanium trilobum (Haeckel)

Dictyopodium trilobum Haeckel, 1860 , p. $839 ; 1862$, p. 340 , pl. 8 , figs. 6-10.

Pterocanium trilobum (Haeckel), Nigrini, 1970, p. 170, pl. 3, fig. 9. Pterocanium trilobum (Haeckel), Kling, 1973, pl. 4, figs. 5-8.

\section{Saturnalis circularis Haeckel}

Saturnalis circularis Haeckel, 1887, p. 131.

Saturnalis circularis Haeckel, Nigrini, 1967, p. 25, pl. 1, fig. 9.

Saturnalis circularis Haeckel, Kling, 1973, p. 635, pl. 1, figs. 21-25; pl. 7.

\section{Sethocorys sp.}

(Plate 1, Fig. 3)

Sethocorys Haeckel, 1881, p. 430.

Sethocorys spp., Kling, 1973, p. 639, pl. 12, figs. 15-18.

\section{Siphostichoartus sp. cf. S. corona (Haeckel)}

(Plate 1, Fig. 15)

Cyrtophormis (Acanthocyrtis) cornona Haeckel, 1887, p. 1462, pl. 77, fig. 15 .

Phormostichoartus corona (Haeckel), Riedel and Sanfilippo, 1971, p. 1600 , pl. $1 \mathrm{~J}$, figs. 13-15; pl. 2J, figs. 1-5.

Siphostichoartus corona (Haeckel), Nigrini, 1977, p. 257, pl. 2, figs. 5,6 .

\section{Sphaeropyle langii Dreyer}

Sphaeropyle langii Dreyer, 1889, p. 13, pl. 4, fig. 54.

Sphaeropyle langii Dreyer, Kling, 1973, p. 634, pl. 1, figs. 5-10; pl. 13, figs. 6-8.
Spirema sp.

Spirema Haeckel, 1881, p. 464.

Spirema sp., Kling, 1973, p. 635,pl. 7, figs. 23-25.

\section{Spirocyrtis sp. cf. S. scalaris Haeckel}

Spirocyrtis scalaris Haeckel, 1887, p. 1509, pl. 76, fig. 14.

Spirocyrtis sp. aff. Spirocyrtis scalaris Haeckel, Riedel and Sanfilippo, 1971, pl. 1G, figs. 19-24; pl. 2H, figs. 3, 15-18.

\section{Spongaster pentas Riedel and Sanfilippo}

Spongaster pentas Riedel and Sanfilippo, 1970, p. 523, pl. 15, fig. 3. Spongaster pentas Riedel and Sanfilippo, 1971, p. 1589, pl. 1D, figs. 5-7.

\section{Spongaster tetras Ehrenber}

Spongaster tetras Ehrenberg, 1860, p. 833; 1872(b), pl. 6, fig. 8. Spongaster tetras Ehrenberg, Riedel and Sanfilippo, 1971, p. 1589, pl. 1D, figs. 2-4.

\section{Spongaster tetras irregularis Nigrini}

(Plate 4, Fig. 1)

Spongaster tetras irregularis Nigrini, 1967, p. 43, pl. 5, fig.2.

Spongaster tetras irregularis Nigrini, Foreman, 1975, p. 619, pl. 9 , fig. 27.

\section{Spongocore puella Haeckel}

Spongocore puella Haeckel, 1887 , p. 347 , pl. 48 , fig. 6 .

Spongocore lata Campbell and Clark, 1944, p. 22, pl. 3, figs. 7-9.

Spongocore puella Haeckel, Kling, 1973, p. 635, pl. 7, figs. 18-22.

\section{Spongotrochus? glacialis Popofsky}

Spongotrochus glacialis Popofsky, 1908, p. 228, pl. 26, fig. 8; pl. 27, fig. 1 ; pl. 28, fig. 2 .

Spongotrochus? glacialis Popofsky, Riedel, 1958, p. 227, pl. 2, figs. $1,2$.

Spongotrochus? glacialis Popofsky, Kling, 1973, p. 635, pl. 2, figs. 4-6.

\section{Stichocorys armata (Haeckel)}

(Plate 1, Fig. 9)

Cyrtophormis armata Haeckel, 1887, p. 1460, pl. 78, fig. 17.

Stichocorys armata (Haeckel), Riedel and Sanfilippo, 1971, p. 1595, pl. 2E, figs. 13-15.

Stichocorys armata (Haeckel), Kling, 1973, p. 638, pl. 13, fig. 11

\section{Stichocorys delmontensis (Campbell and Clark)}

(Plate 1, Figs. 10-11)

Eucyrtidium delmontensa Campbell and Clark, 1944, p. 56, pl. 7, figs. 19, 20.

Stichocorys delmontensis (Campbell and Clark), Riedel and Sanfilippo, 1971, p. 1595, pl. 1F, figs. 5-7; pl. 2E, figs. 10, 11 .

Stichocorys delmontensis (Campbell and Clark), Dinkelman, 1973, p. 783 , pl. 9 , fig. 1 .

Stichocorys delmontensis (Campbell and Clark), Kling, 1973, p. 638, pl. 11, figs. 8-10.

\section{Stichocorys diploconus (Haeckel)}

Cyrtocapsa diploconus Haeckel, 1887, p. 1513, pl. 78, fig. 6 .

Stichocorys diploconus (Haeckel), Riedel and Sanfilippo, 1971, p. 1595, pl. 2E, fig. 16.

Stichocorys diploconus (Haeckel), Kling, 1973, p. 638, pl. 11, fig. 11; pl. 13, fig. 12.

\section{Stichocorys peregrina (Riedel)}

(Plate 1, Figs. 6-8)

Eucyrtidium elongatum peregrinum Riedel, 1953, p. 812, pl. 85, fig. 2. Stichocorys peregrina (Riedel), Riedel and Sanfilippo, 1971, p. 1595 , pl. 1 F, figs. 2-4; pl. 8, fig. 5 .

Stichocorys peregrina (Riedel), Riedel and Sanfilippo, 1971, p. 1595, pl. 1F, figs. 2-4; pl. 8, fig. 5 . 
Stichocorys peregrina (Riedel), Kling, 1973, p. 638, pl. 4, fig. 27; pl. 11, fig. 29; pl. 13, figs. 9, 10.

\section{Stichocorys wolffii Haeckel}

(Plate 1, Figs. 1-2)

Stichocorys wolffii Haeckel, 1887, p. 1497, pl. 80, fig. 10.

Stichocorys wolffii Haeckel, Riedel and Sanfilippo, 1971, p. 1595, pl. 2E, figs. 8, 9.

Stichocorys wolffii Haeckel, Moore, 1971, p. 742, pl. 13, fig. 8.

Stichopera pectinata Haeckel group (Plate 4, Fig. 5)

Stichopera pectinata Haeckel, 1887, p. 1449, pl. 75, fig. 11.

Stichopera pectinata Haeckel, Kling, 1973, p. 638, pl. 3, figs. 25-27; pl. 10, figs. 1-5.

\section{Stylacontarium acquilonium (Hays)}

Druppatractus acquilonius Hays, 1970, p. 214, pl. 1, figs. 4, 5. Stylacontarium acquilonium (Hays), Kling, 1973, p. 634, pl. 1, figs. $17-20$; pl. 14, figs. $1-4$.

\section{Stylacontarium sp. aff. S. bispiculum Popofsky}

Stylacontarium bispiculum Popofsky, 1912, p. 91, pl. 2, fig. 2.

Stylacontarium sp. aff. S. bispiculum Popofsky, Kling, 1973, p. 634, pl. 6, figs. 19-23; pl. 14, figs. 5-8.

\section{Theocalyptra davisiana (Ehrenberg)}

Cycladophora? davisiana Ehrenberg, 1861, p. 297; 1873, pl. 2, fig. 11. Theocalyptra davisiana (Ehrenberg), Riedel, 1958, p. 239, pl. 4, figs. $2,3$.

Theocalyptra davisiana (Ehrenberg), Kling, 1973, p. 638, pl. 3, figs. 9-12, 28.

\section{Theoconus sp. cf. $T$, zancleus (Müller)}

$$
\text { (Plate 1, Fig. 5) }
$$

Eucyrtidium zancleum Müller, 1855, p. 672; 1858, pl. 6, figs. 1-3. Theoconus zancleus (Müller), Haeckel, 1877, p. 1399.

Theoconus zancleus (Müller), Kling, 1973, p. 639, pl. 5, figs. 9-11.

Theocorys sp. cf. T. redondoensis (Campbell and Clark) (Plate 1, Fig. 14)

Theocyrtis redondoensis Campbell and Clark, 1944, p. 49, pl. 7, fig. 4. Theocorys redondoensis (Campbell and Clark), Kling, 1973, p. 638, pl. 11, figs. 26-28.

\section{Theocorythium trachelium trachelium (Ehrenberg)}

Eucyrtidium trachelius Ehrenberg, 1872(b), p. 293, pl. 7, fig. 8. Calocyclas amicae Haeckel, 1887, p. 1382, pl. 74, fig. 2.

Theocorythium trachelium trachelium (Ehrenberg), Nigrini, 1967, p. 79 , pl. 8, fig. 2; pl. 9, fig. 2.

Theocorythium trachelium trachelium (Ehrenberg), Dinkelman, 1973, p. 788, pl. 10, figs. 8, 9; Foreman, 1975, pl. 9, fig. 12.

\section{Theocorythium vetulum Nigrini}

Theocorythium vetulum Nigrini, 1971, p. 447, pl. 34.1, figs. 6a, b. Theocorythium vetulum Nigrini, Dinkelman, 1973, p. 788, pl. 10, figs. 11,$12 ; 1975$, p. 620 , pl. 9 , fig. 11 .

\section{Xiphospira sp. cf. X. circularis (Clark and Campbell)}

Porodiscus circularis Clark and Campbell, 1942, p. 42, pl. 2, figs. 2, $6,10$.

Xiphospira circularis (Clark and Campbell), Sanfilippo and Riedel, 1973 , p. 526, pl. 14, figs. 5-12; pl. 31, figs. 4-7.

Xiphospira cf. circularis (Clark and Campbell), Kling, 1973, p. 635, pl. 2, figs. 1-3; pl. 7, figs. 11-17.

\section{ACKNOWLEDGMENTS}

The writer wishes to thank his co-scientists on Leg 63, John Barron, Dave Bukry, and Dick Poore, for valuable discussions on Leg 63 biostratigraphic problems. The manuscript was improved by the critical reviews of W. R. Riedel and S. A. Kling.

\section{REFERENCES}

Campbell, A. S., and Clark, B. L., 1944. Miocene radiolarian faunas from southern California. Geol. Soc. Am. Spec. Pap., 51:1-76.

Caulet, J., 1971. Contribution à l'étude de quelques Radiolaires Nasselaires des boues de la Méditerranée et du Pacifique. Arch. Orig. Documentation CNRS, Cah. Micropaleontol., 2, 10, 498:1-10.

Clark, B. L., and Campbell, A. S., 1942. Eocene radiolarian faunas from the Mt. Diablo Area, California. Geol. Soc. Am. Spec. Pap., 39:1-112.

Dinkelman, M. G., 1973. Radiolarian Stratigraphy: Leg 16, Deep Sea Drilling Project. In van Andel,. Tj. H., Heath, G. R., et al., Init. Repts. DSDP, 16: Washington (U.S. Govt. Printing Office), 747-813.

Dogiel, V. A., and Reshetnyak, V. V., 1952. Materialy po radiolyariyam severi-zapadnoi chasti Tikhogo okeana. Issled. Dal'nevost. Morei SSSR, 3:5-36.

Dreyer, F., 1889. Die Pylombildungen in vergleichend-anatomischer und entwicklungsgeschichtlicher Beziehung bei Radiolarien und bei Protisten überhaupt. Jena, Z. Naturwiss., 23(N.F. 16):77.

Dumitricá, P., 1973. Cretaceous and Quaternary radiolaria in deep sea sediments from the Northwest Atlantic Ocean and Mediterranean Sea. In Ryan, W. B. F., Hsü, K. J., et al., Init. Repts. DSDP, 13: Washington (U.S. Govt. Printing Office), 829-901.

Ehrenberg, C. G., 1838. Über die Bildung der Kreidefelsen und des Kreidemergels durch unsichtbare Organismen. K. Acad. Wiss. Berlin, Abh., für 1838:59-147.

1844. Über 2 neue Lager von Gebirgsmassen aus Infusorien als Meeres-Absatz in Nord-Amerika und eine Vergleichung derselben mit den organischen Kreide-Gebilden in Europa und Afrika. K. Preuss. Acad. Wiss. Berlin, Ber., für 1844:57-97.

1847. Über die mikroskopischen kieselschaligen Polycystinen als mächtige Gebirgsmasse von Barbados und über das Verhältnis der aus mehr als 300 neuen Arten bestehenden ganz eigenthümlichen Formengruppe jener Felsmasse zu den jetzt lebenden Thieren und zur Kreidebildung. Eine neue Anregung zur Erforschung des Erdlebens. K. Preuss. Acad. Wiss. Berlin, Ber., für $1847: 40-60$. (Voss).

1854. Mikrogeologie, Atlas, Fortsetzung (1856): Leipzig

1858. Kurze Charakteristik der 9 neuen Genera und der 105 neuen Species des ägäischen Meeres und des Tiefgrundes des Mittelmeeres. K. Preuss. Acad. Wiss., Monatsber., f. 1858:10.

1860. Über den Tiefgrund des Stillen Oceans zwischen Californien und den Sandwich-Inseln aus bis $15600^{\prime}$ Tiefe nach Lieut. Brooke. K. Preuss. Acad. Wiss. Berlin, Monatsber., für 1860:819833.

1861. Über die Tiefgrund-Verhältnisse des Oceans am Eingange der Davisstraße und bei Island. K. Preuss. Acad. Wiss. Berlin, Monatsber., für. 1861:275-315.

1872a. Mikrogeologische Studien als Zusammenfassung der Beobachtungen des kleinsten Lebens der Meeres-Tiefgründe aller Zonen und dessen geologischen Einfluß. K. Preuss. Acad. Wiss. Berlin, Monatsber., für 1872:265-322.

1872 b. Mikrogeologische Studien über das kleinste Leben der Meeres-Tiefgründe aller Zonen und dessen geologischen Einfluß. K. Acad. Wiss. Berlin, Abhandl., für 1872:131-399.

Foreman, H. P., 1975. Radiolaria from the North Pacific, Deep Sea Drilling Project, Leg 32. In Larson, R. L., Moberly, R., et al., Init. Repts. DSDP, 32: Washington (U.S. Govt. Printing Office), 579-676.

Haeckel, E., 1860. Abbildungen und Diagnosen neuer Gattungen und Arten von lebenden Radiolarien des Mittelmeeres. K. Preuss. Acad. Wiss. Berlin, Monatsber., für 1860:835-845.

mer). 1862. Die Radiolarien. (Rhizopoda, Radiaria): Berlin (Rei-

, 1881. Entwurf eines Radiolarien-Systems auf Grund von Studien der Challenger-Radiolarien. Jena. Z. Med. Naturwiss., 15:418-472.

, 1887. Report on the Radiolaria collected by H.M.S. Challenger during the years 1873-76. Rept. Voyage Challenger, Zool., 18:1-1803. 
Hays, J. D., 1965. Radiolaria and late Tertiary and Quaternary history of Antarctic Seas. Biology of Antarctic Seas II. Antarct. Res. Ser., 5:124-184.

1970. Stratigraphy and evolutionary trends of Radiolaria in North Pacific Deep-Sea sediments. In Hays, J. D. (Ed.), Geological investigations of the North Pacific: Geol. Soc. Am. Mem. 126:185-218.

Kling, S. A., 1973. Radiolaria from the Eastern North Pacific, Deep Sea Drilling Project, Leg 18. In Kulm, L. D., von Huene, R., et al., Init. Repts. DSDP, 18: Washington (U.S. Govt. Printing Office), 617-671.

1979. Vertical distribution of Polycystine radiolarians in the central North Pacific. Mar. Micropaleontol., 4:295-318.

Ling, H.-Y., and Anikouchine, W. A., 1967. Some Spumellarian Radiolaria from the Java, Philippine, and Mariana trenches. J. Paleontol., 6:1481-1491.

Martin, G. C., 1904. Radiolaria. Maryland Geol. Surv. (Miocene): Baltimore (John Hopkins Press), pp. 447-459.

Moore, T. C., 1971. Radiolaria. In Tracey, J. I., Jr., Sutton, G. H., et al., Init. Repts. DSDP, Washington (U.S. Govt. Printing Office), 8:727-775.

Müller, J., 1855. Über die im Hafen von Messina beobachteten Polycystinen. K. Preuss. Acad. Wiss. Berlin, Ber., f. 1855:671-674.

Nakaseko, K., 1963. Neogene Cyrtoidea (Radiolaria) from the Isozaki Formation in Ibaraki Prefecture, Japan. Sci. Rep. Osaka Univ., 12, 2:165-198.

Nigrini, C., 1967. Radiolaria in pelagic sediments from the Indian and Atlantic Oceans. Bull. Scripps Inst. Oceanogr., 11:1-125.

1970. Radiolarian assemblages in the North Pacific and their application to a study of Quaternary sediments in Core V 20-130. In Hays, J. D. (Ed.), Geological Investigations of the North Pacific: Geol. Soc. Am. Mem., 126:139-183.

1971. Radiolarian zones for the Quaternary of the equatorial Pacific Ocean. In Funnell, B. M., and Riedel, W. R. (Eds.), The Micropaleontology of Oceans: Cambridge (Cambridge Univ. Press), pp. 443-461.

1977. Tropical Cenozoic Artostrobiidae (Radiolaria). Micropaleontology, 23, 3:241-269.

Petrushevskaya, M. G., 1971. Radiolyarii Nassellaria v planktone mirovogo okeana. (Radiolaria Nassellaria of the world ocean). Akad. Nauk SSSR, Zool. Inst. Issled. Fauny Morei, 9(17):3-295.

Popofsky, A., 1908. Die Radiolarien der Antarktis (mit Ausnahme der Tripyleen). Deutsche Sudpolar-Expedition 1901-1903, 10(3): $1-305$.
, 1912. Die Sphaerellarien des Warmwassergebietes. Deutsche Südpolar-Expedition 1901-1903, 13(Zool. 5), 2:73.

Riedel, W. R., 1953. Mesozoic and Late Tertiary Radiolaria of Rotti. J. Paleontol., 27, 6:805-813.

1957. Radiolaria: a preliminary stratigraphy. Rep. Swed. Deep-Sea Exped., 6, 3:59-96.

1958. Radiolaria in Antarctic sediments. Rep. B.A.N.Z. Antarct. Res. Exped., B6, 10:217-255.

1959. Oligocene and lower Miocene Radiolaria in tropical Pacific sediments. Micropaleontology, 5, 3:285-302.

, 1967a. Subclass Radiolaria. In Harland, W. B., et al. (Eds.), The Fossil Record: London (Geol. Soc. London), pp. 291298.

1967b. Some new families of Radiolaria. Proc. Geol. Soc. London, 1640:148-149.

Riedel, W. R., and Sanfilippo, A., 1970. Radiolaria, Leg 4, Deep Sea Drilling Project. In Bader, R. G., Gerard, R. D., et al., Init. Repts. DSDP, 4: Washington (U.S. Govt. Printing Office), 503575 .

1971. Cenozoic Radiolaria from the western tropical Pacific, Leg 7. In Winterer, E. L., Riedel, W. R., et al., Init. Repts. $D S D P, 7$, Pt. 2: Washington (U.S. Govt. Printing Office), 15291672.

1978. Stratigraphy and evolution of tropical Cenozoic radiolarians. Micropaleontology, 24, 1:61-96.

Sanfilippo, A., and Riedel, W. R., 1970. Post-Eocene "closed" theoperid radiolarians. Micropaleontology, 16, 4:446-462.

1973. Cenozoic Radiolaria (exclusive of the theoperids, artostrobiids, and amphipyndacids) from the Gulf of Mexico. In Worzel, J. L., Bryant, W., et al., Init. Repts. DSDP, 10: Washington (U.S. Govt. Printing Office), 475-611.

Theyer, F., and Hammond, S. R., 1974. Cenozoic magnetic time scale in deep-sea sediments: completion of the Neogene. Geology, 2: 487-492.

Theyer, F., Mato, C. Y., and Hammond, S. R., 1978. Paleomagnetic and geochronologic calibration of latest Oligocene to Pliocene radiolarian events, equatorial Pacific. Mar. Micropaleontol., 3:377395.

Westberg, M. J., and Riedel, W. R., 1978. Accuracy of radiolarian correlations in the Pacific Miocene. Micropaleontology, 24, 1: $1-23$. 


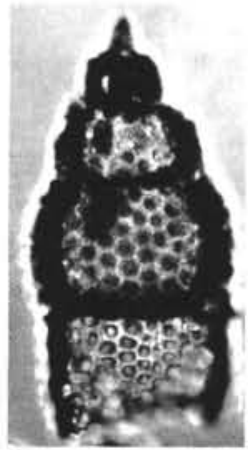

1

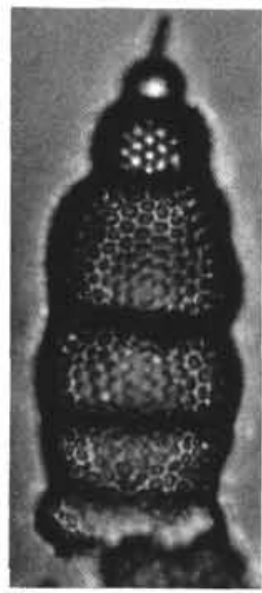

6

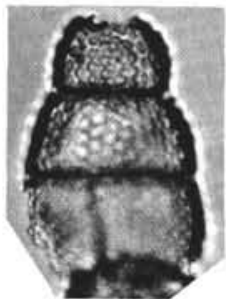

7

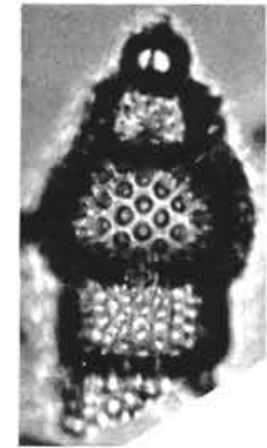

2

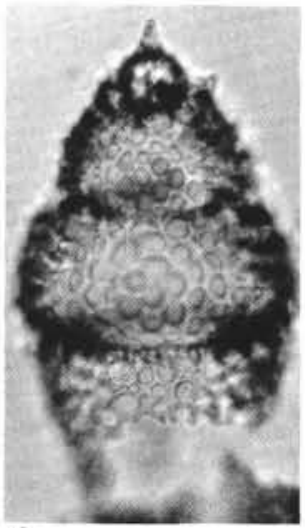

9

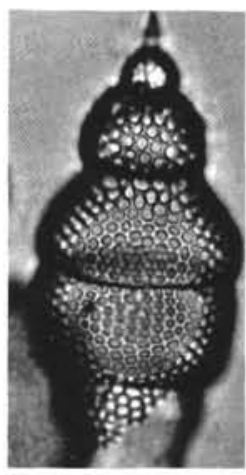

8

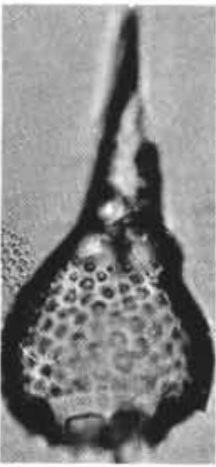

3

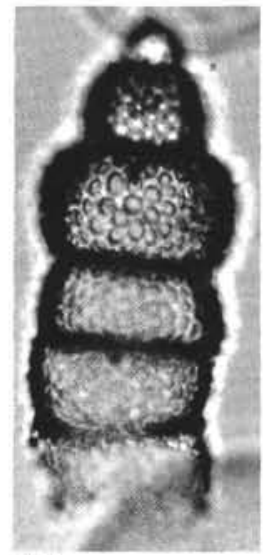

10

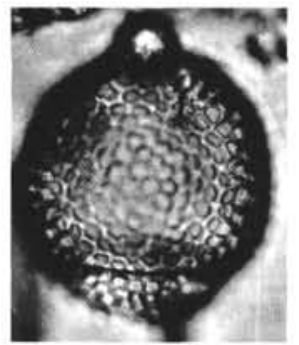

13

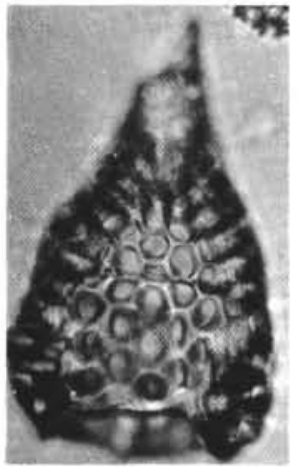

4

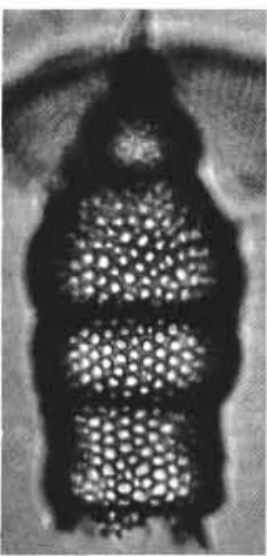

11

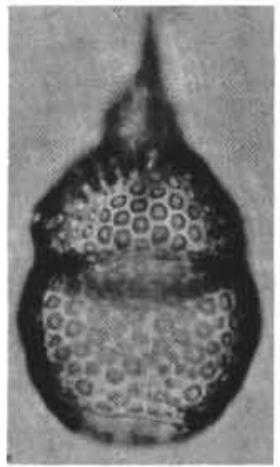

5

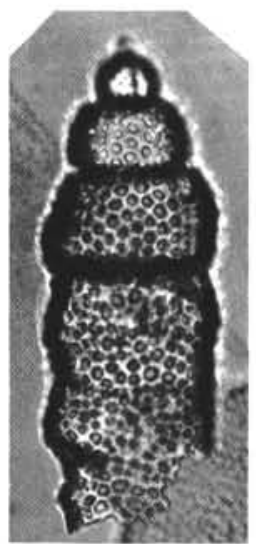

12

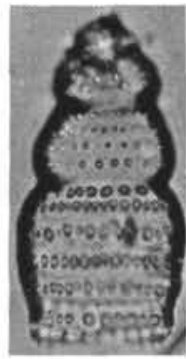

15

Plate 1. (The figures on Plates 1 through 5 cover the 11 different horizons of the Pleistocene through middle Miocene. Magnifications are $\times 240$. The samples used for the illustrations are noted for each figure. All slides have BGR numbers; they are deposited in the Bundesanstalt für Geowissenschaften und Rohstoffe, BGR (Federal Institute for Geosciences and Natural Resources), Postfach 510153, D-3000 Hannover, 51, Federal Republic of Germany.) 1-2. Stichocorys wolffii Haeckel, (1) Sample 469-30-1, 34-36 cm. D. alata Zone, BGR-R 1149, (2) Sample 468B-17-4, 54-56 cm. D. alata Zone, BGR-R 1060. 3. Sethocorys sp. Sample 469-20-1, 105-107 cm. C. petterssoni Zone, BGR-R 1134. 4. Lamprocyrtis hannai (Campbell and Clark). Sample 469-17-1, 40-42 cm. O. penultimus/O. antepenultimus Zone, BGR-R 1132. 5. Theoconus sp. cf. T. zancleus (Müller). Sample 467-2-1, 14-16 cm. B. miralestensis/A. angelinum Zone, BGR-R 795. 6-8. Stichocorys peregrina (Riedel), $(6,7)$ Sample 471-12-5, 40-42 cm. BGR-R 1351, (8) Sample 471-13-7, 40-42 cm. BGR-R 1360; both samples are from the lower S. peregrina Zone. 9. Stichocorys armata (Haeckel). Sample 468-18-5, 51-53 cm. D. alata Zone, BGR-R 995. 10-11. Stichocorys delmontensis (Campbell and Clark), (10) Sample 472-7-1, 60-62 cm. O. antepenultimus Zone, BGR-R 1431, (11) Sample 471-15-3, 40-42 cm. O. penultimus Zone, BGRR 1366. 12. Stichocorys sp. Sample 472-10-1, 60-62 cm. C. petterssoni Zone, BGR-R 1446. 13. Lithopera renzae Sanfilippo and Riedel. Sample 468-5-3, 133-135 cm. D. alata Zone, BGR-R 1178. 14. Theocorys sp. cf. T. redondoensis (Campbell and Clark). Sample 469-20-1, 105-107 $\mathrm{cm}$. C. petterssoni Zone, BGR-R 1173. 15. Siphostichoartus sp. cf. S. corona (Haeckel). Sample 469-20-1, 105-107 cm, C. petterssoni/D. alata Zone, BGR-R 1134. 


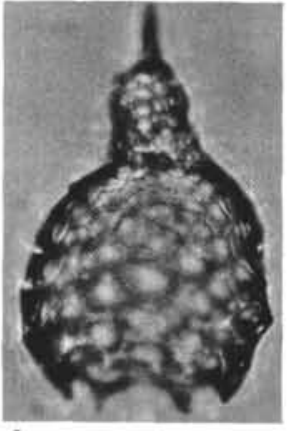

1

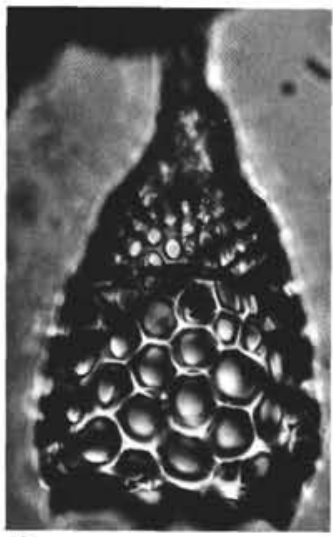

6

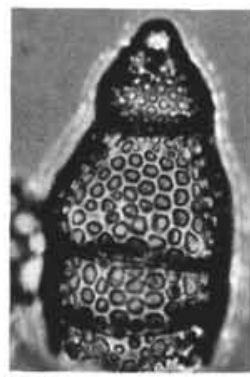

12

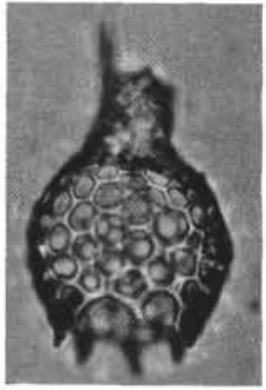

2

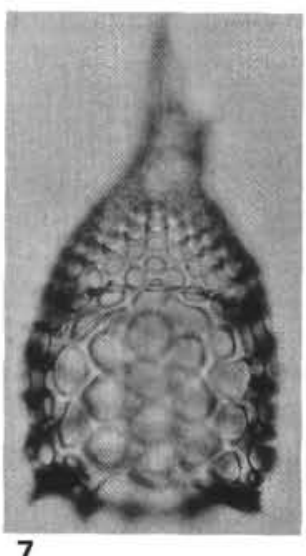

7

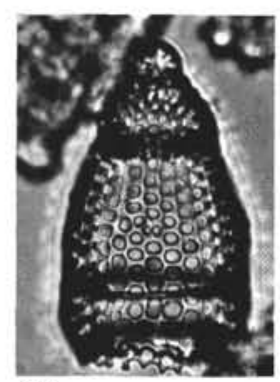

13

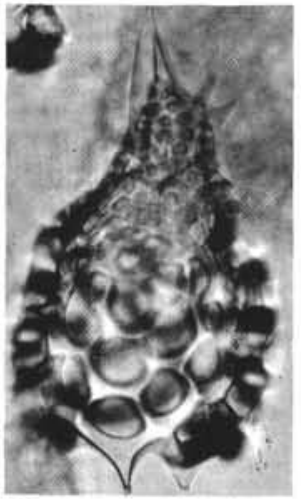

3

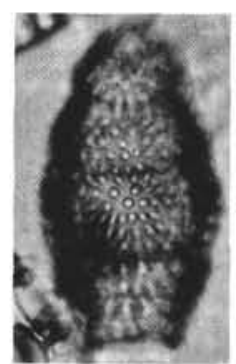

8

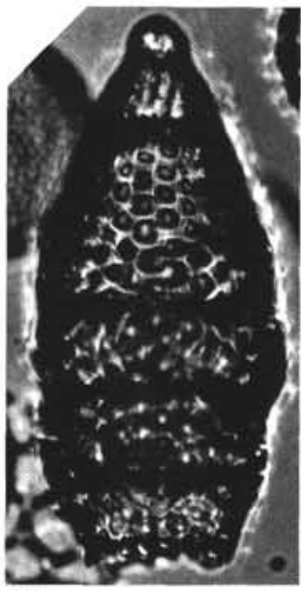

14

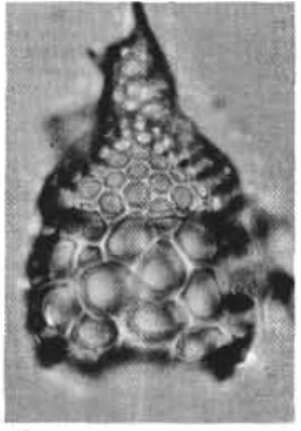

4

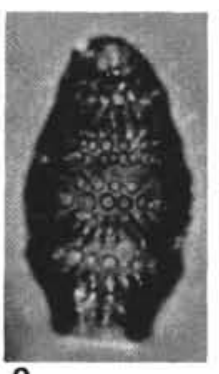

9

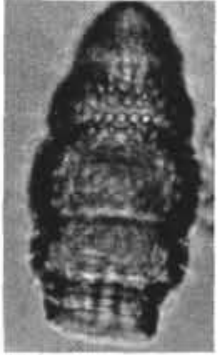

10

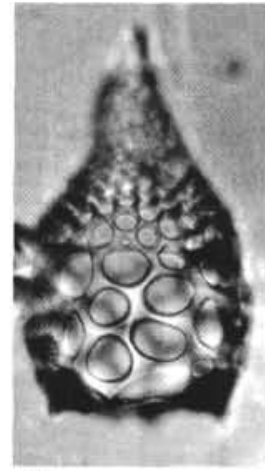

5

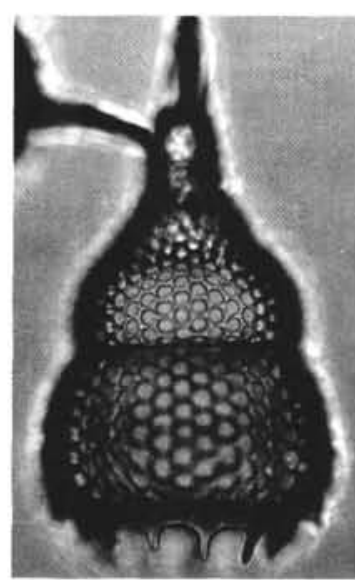

11

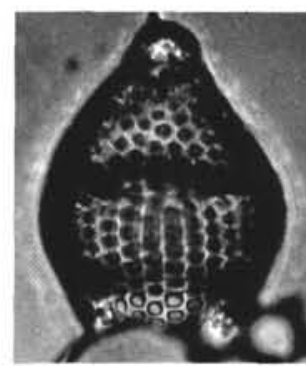

15

$100 \mu \mathrm{m}$

Plate 2. 1-2. Lamprocyrtis nigriniae (Caulet). Sample 467-2-1, 14-16 cm. B. miralestensis/A. angelinum Zone, BGR-R 795. 3 and 5(?). Lamprocyrtis neoheteroporos Kling. Sample 468A-1-4, 55-57 cm. E. matuyamai Zone, BGR-R 1000, 4, 6, 7. Lamprocyrtis heteroporos (Hays), (6, 7) Sample 469-7-2, 30-32 cm. L. heteroporos Zone, BGR-R1100, (4) Sample 467-35-1, 53-56 cm. Upper S. peregrina Zone, BGR-R 920. 8-10. Botryostrobus miralestensis (Campbell and Clark); $(8,10)$ Sample 468A-1-4, 55-57 cm. E. matuyamai Zone, BGR-R 1000, (9) Sample 467-2-1, 14-16 cm. B. miralestensis/A. angelinum Zone, BGR-R 795. 11. Lamprocyclas maritalis maritalis Haeckel. Sample 471-7-2, 75-77 $\mathrm{cm}$. Upper $S$. peregrina Zone, BGR-R 1318. 12-14. Eucyrtidium calvertense Martin, (12) Sample 467-25-6, 78-80 cm. L. heteroporos Zone, BGR-R 892, (13) Sample 467-26-2, 60-62 cm. Upper S. peregrina Zone, BGR-R 896, (14) Sample 467-19-6, 24-26 cm. L. heteroporos Zone, BGR-R 875. 15. Eucyrtidium inflatum Kling. Sample 468B-17-2, 54-56 cm. D. alata Zone, BGR-R 1058. 


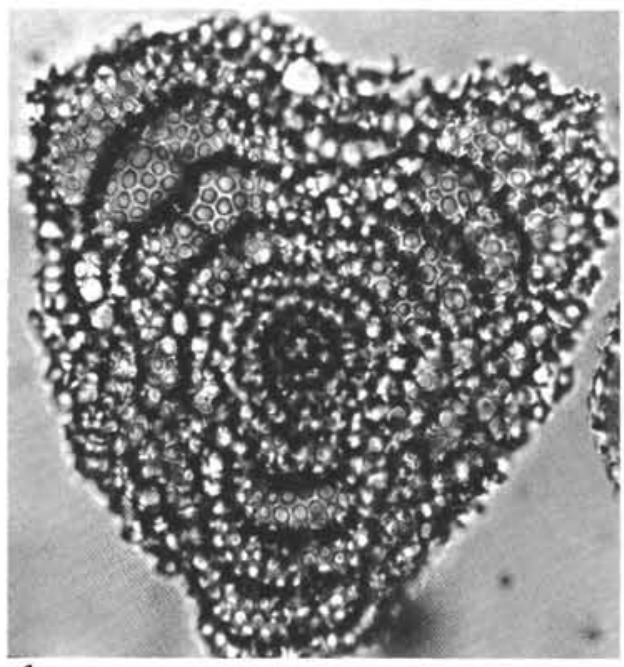

1

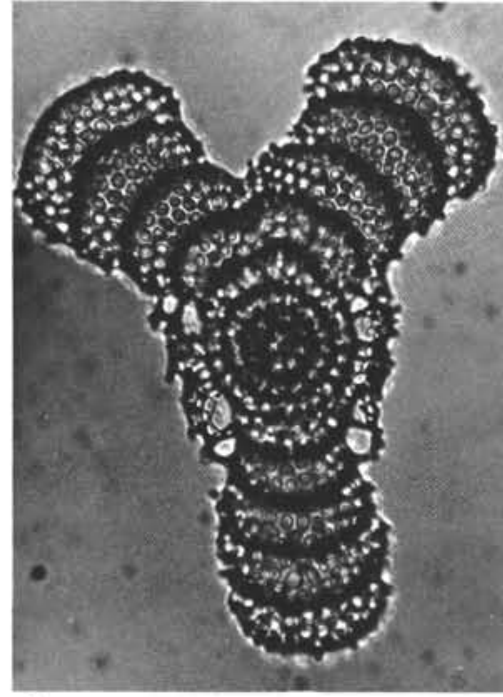

2

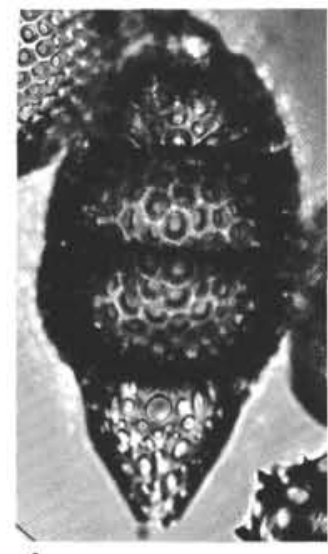

4

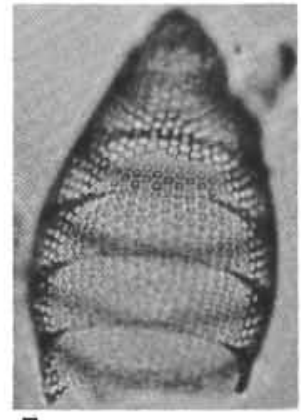

7

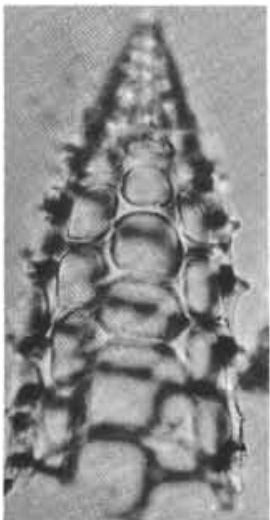

11
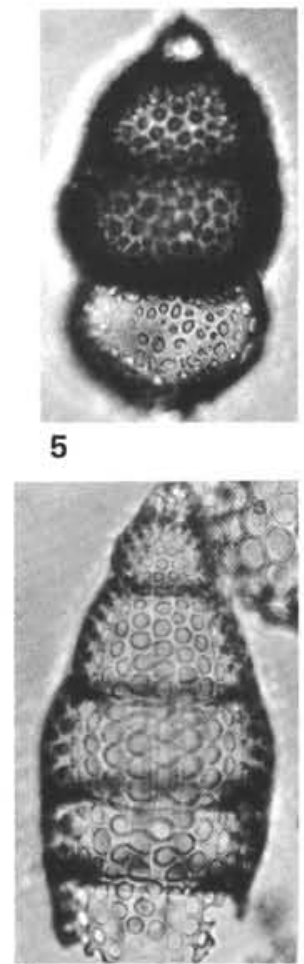

8

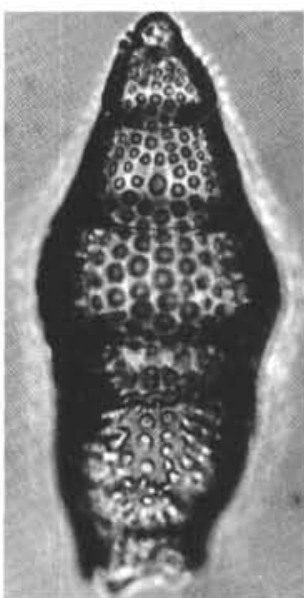

10

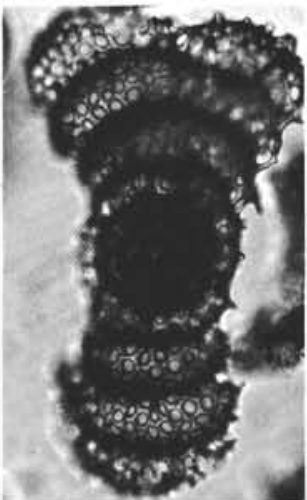

3

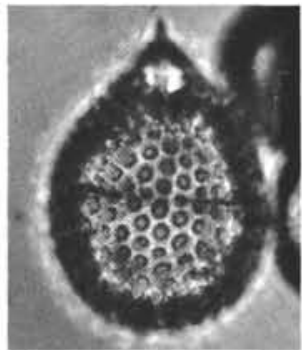

6

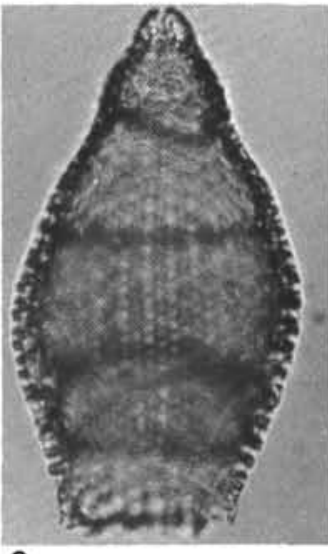

$100 \mu \mathrm{m}$

Plate 3. 1-3. Amphirhopalum wirchowii (Haeckel), (1) Sample 469-5-3, 80-82 cm. E. matuyamai Zone, BGR-R 1090, (2) Sample 469-3-1, 40-42 $\mathrm{cm}$. B. miralestensis/A. angelinum Zone, BGR-R 1077, (3) Sample 467-6,CC. B. miralestensis/A. angelinum Zone, BGR-R 818a. 4. Cyrtocapsella tetrapera Haeckel. Sample 468B-6-5, 60-62 cm. D. alata Zone, BGR-R 1032. 5-6. Cyrtocapsella japonica (Nakaseko), (5) Sample 470-12-1, 6-8 cm. O. antepenultimus Zone, BGR-R 1251, (6) Sample 469-30-1, 34-36 cm. D. alata Zone, BGR-R 1149. 7. Eucyrtidium acuminatum (Ehrenberg). Sample 467-2-1, 14-16 cm. B. miralestensis/A. angelinum Zone, BGR-R 795. 8-9. Eucyrtidium matuyamai Hays. Sample 468A-1-4, 55-57 cm. E. matuyamai Zone, BGR-R 1000. 10. Eucyrtidium sp. cf. E. matuyamai Hays. Sample 469-5-3, 80-82 cm. E. matuyamai Zone, BGR-R 1090. 11. Peripyramis circumtexta Haeckel. Sample 468A-1-4, 55-57 cm. E. matuyamai Zone, BGR-R 1000. 


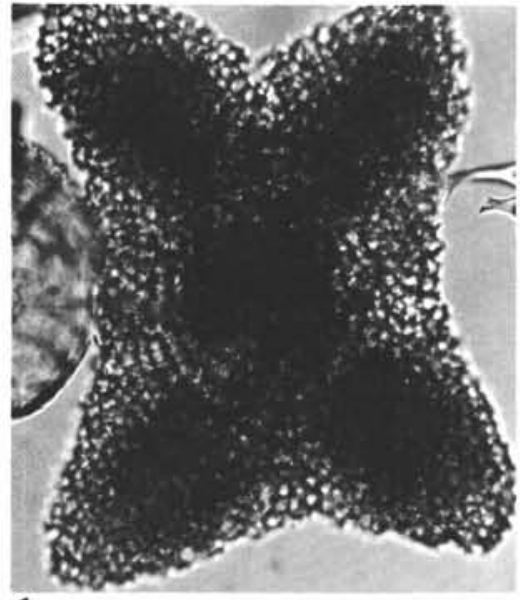

1

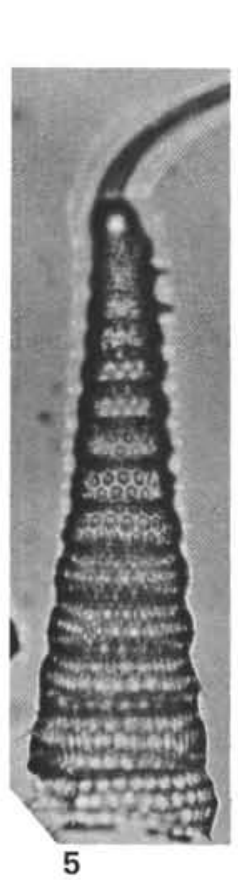

5

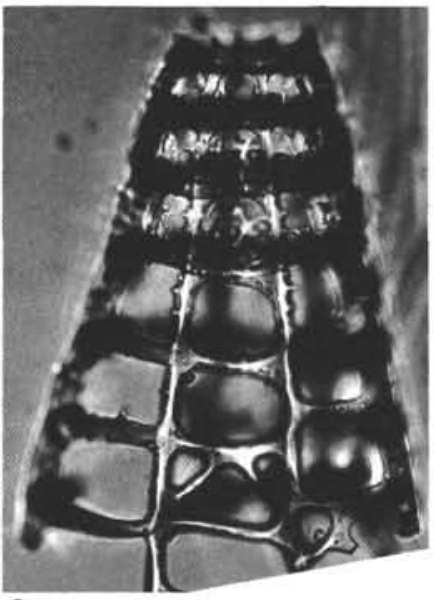

2

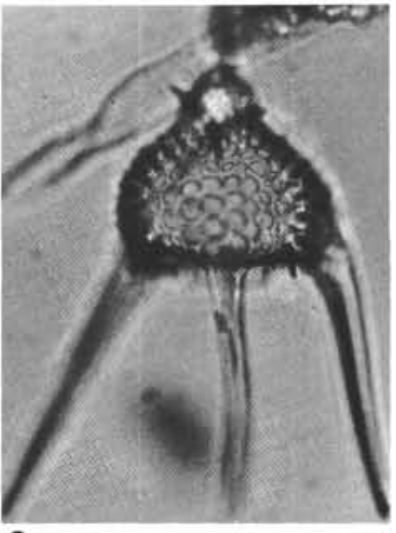

3

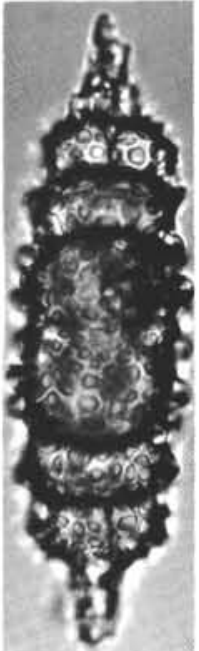

4
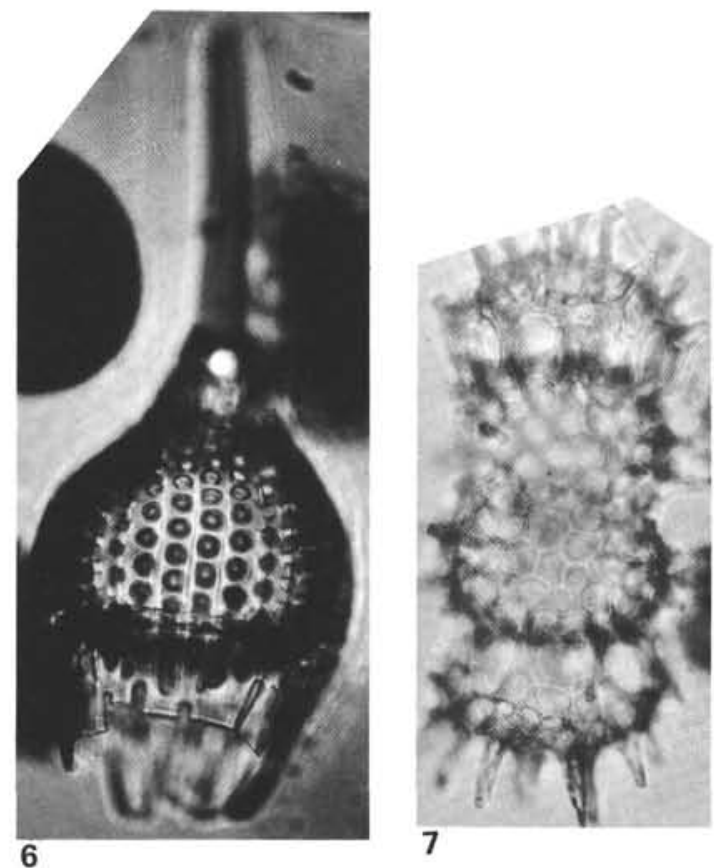

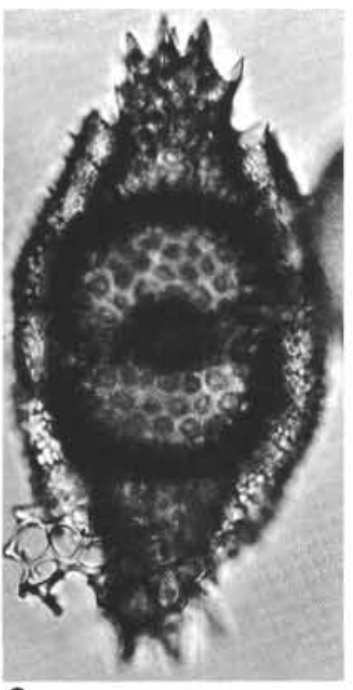

8

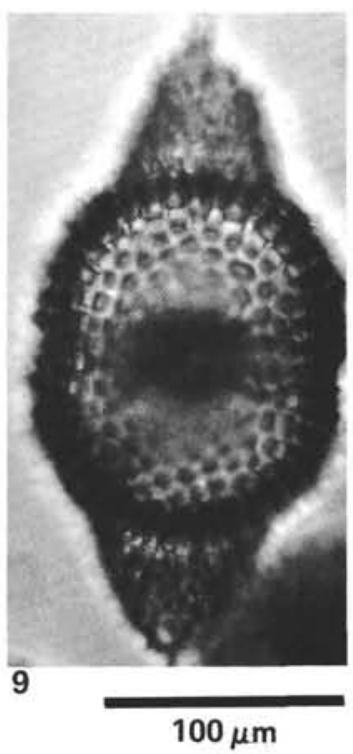

Plate 4. 1. Spongaster tetras irregularis Nigrini. Sample 469-1-2, 53-55 cm. B. miralestensis/A. angelinum Zone, BGR-R 1070. 2. Bathropyramis woodringi Campbell and Clark. Sample 467-33-4, 35-37 cm. Upper S. peregrina Zone, BGR-R 916. 3. Pterocanium korotnevi (Dogiel and Reshetnyak). Sample 467-2-1, 14-16 cm. B. miralestensis/A. angelinum Zone, BGR-R 795. 4. Ommatartus sp. cf. Cannartus bassanii (Carnevale), cf. sensu Foreman, 1975, pl. 8, figs. 11-12. Sample 471-6-7, 73-75 cm. Upper S. peregrina Zone, BGR-R 1317. 5. Stichopera pectinata Haeckel group. Sample 467-2-1, 14-16 cm. B. miralestensis/A. angelinum Zone, BGR-R 795. 6. Calocycletta costata (Riedel). Sample 468-18-5, 51-53 cm. D. alata Zone, BGR-R 995. 7. Ommatartus tetrathalamus (Haeckel). Sample 473-2-1, 80-82 cm. B. miralestensis/A. angelinum Zone, BGR-R 1454. 8. Ommatartus sp. Sample 472-7-5, 60-62 cm. O. antepenultimus Zone, BGR-R 1435. 9. Cannartus? sp. Sample 470-12-1, 6-8 cm. O. antepenultimus Zone, BGR-R 1251. 

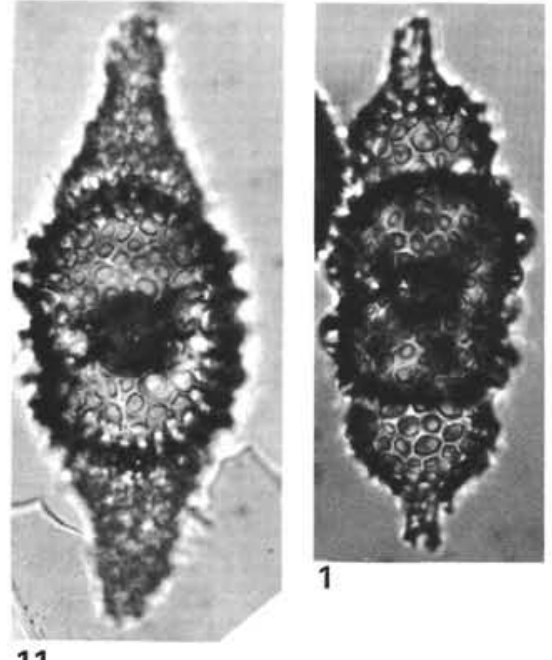

11

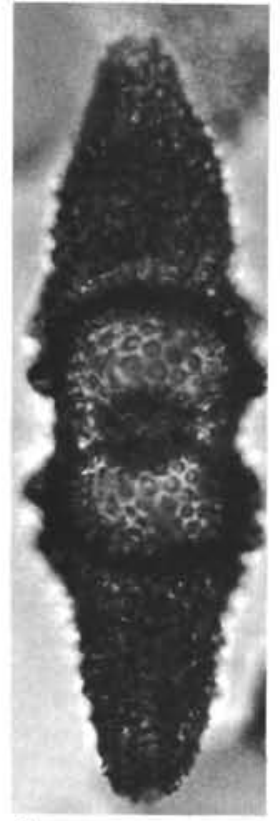

6

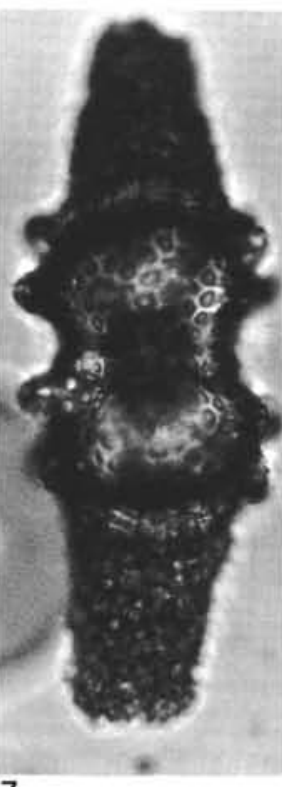

7

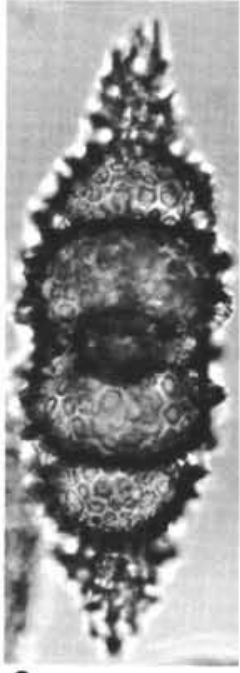

2

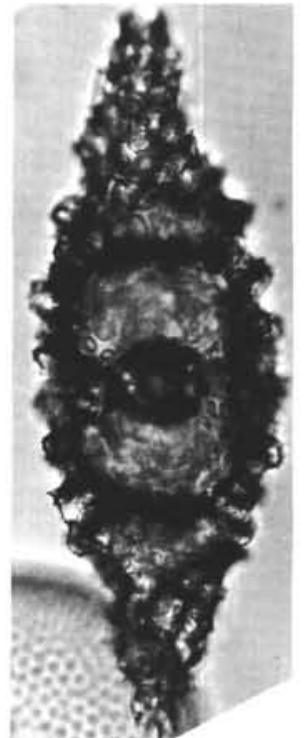

3

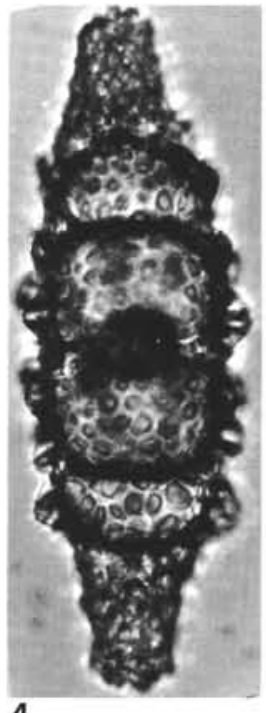

4

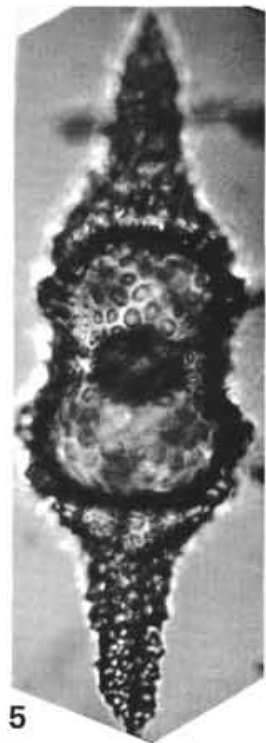

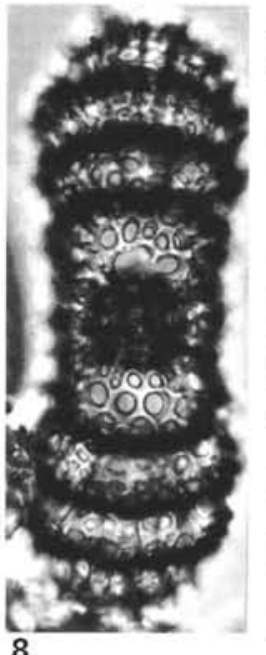

8

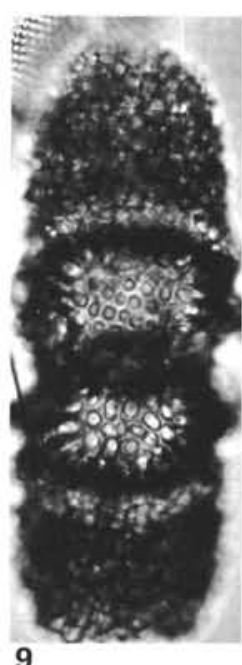

9

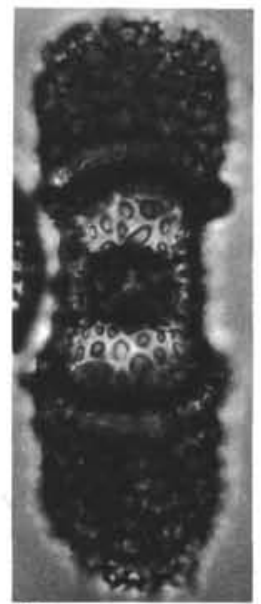

10

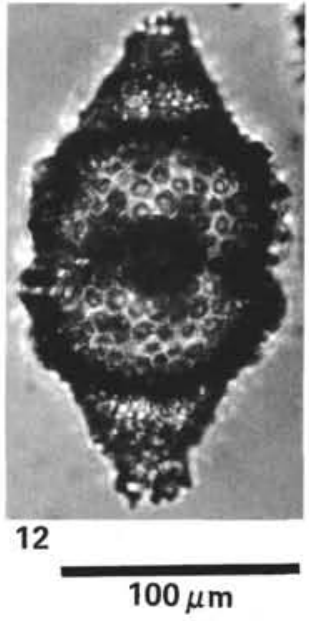

Plate 5. 1-2. Ommatartus penultimus (Riedel), (1) Sample 471-7-2, 75-77 cm. Upper S. peregrina Zone, BGR-R 1318, (2) Sample 470A-4-3, 62-64 $\mathrm{cm}$. O. penultimus Zone, BGR-R 1284. 3-5. Ommatartus antepenultimus Riedel and Sanfilippo, (3) Sample 470-8-3, 70-72 cm. O. penultimus/ lower S. peregrina Zone, BGR-R 1238, (4) Sample 471-14-1, 40-42 cm. O. penultimus Zone, BGR-R 1362, (5) Sample 470-11-1, 70-72 cm. O. antepenultimus Zone, BGR-R 1244. 6-7. Cannartus laticonus Riedel, (6) Sample 470-15-3, 70-72 cm. BGR-R 1264, (7) Sample 470-15-5, 70-72 $\mathrm{cm}$. BGR-R 1266, both samples belong to the C. petterssoni Zone. 8. Ommatartus hughesi (Campbell and Clark). Sample 470-9-1, 70-72 cm. O. penultimus Zone, BGR-R 1239. 9-10. Cannartus petterssoni Riedel and Sanfilippo, (9) Sample 470-12-5, 70-72 cm. O. antepenultimus Zone, BGR-R 1255, (10) Sample 468-2-3, 5-7 cm. C. petterssoni Zone, BGR-R 1163. 11-12. Cannartus sp. cf. C. mammiferus (Haeckel). Sample 469-23-3, 25-27 cm. C. petterssoni/D. alata Zone, BGR-R 1142. 